\title{
Reportage of Rurality by the Nigerian Press: Perspectives on Domestic Communication for Development
}

\author{
Muyiwa Popoola \\ Department of Communication and Media Studies Ajayi Crowther University, Oyo Oyo State, Nigeria
}

\begin{abstract}
Rural development is a basis for economic development and information is an important ingredient in development process. For rural development to be achieved, the press has a role to play. The use of print media in development is supposedly to provide information and sensitize rural people. But, there have been speculations that media professionals as sources of information and mobilization for positive change among the rural populace are not favourably disposed to coverage of rural development news including, given the media environment they operate. But, how these speculations have been empirically tested is lacking in mass media and development literature. Thus, this study was carried out to ascertain the extent of selected newspapers' reportage of rural development, realizing the implications which rural development have for national development. The study determined the reportage of rural development issues in Nigeria within a period of two years (2009 and 2011). The study investigated the extent of social responsibility displayed by selected newspapers in reporting the issues. The newspapers selected for the study included Nigerian Tribune, The Punch, The Guardian and the Daily Sun. The study adopted a combined use of content analysis and dialectical hermeneutics style of textual analysis. The study was conducted within the period of 2009 and 2011.

It was discovered that agricultural development stories and infrastructural development stories were the most reported by the selected newspapers. Cultural stories accounted for the least coverage by the selected newspapers. It was also observed that all the selected newspapers made use of the straight news format most often than the other journalistic genres. By way of general placement of stories, the newspapers gave less prominence to rural development stories by placing the majority of the stories on inside pages. It was also discovered that the selected newspapers placed insignificant premium on rural issues as evident in the inadequate placement of stories on front pages and paucity of in-depth and interpretative analysis of issues.

The research concludes that the selected newspapers devoted a considerable percentage of their overall rural development oriented stories to agricultural development and infrastructural development. It is recommended that every newspaper house should create rural development desk just as there are foreign, sports, business and other desks.
\end{abstract}

\section{Background to The Study}

In Nigeria, a multiplicity of media houses can be found, largely due to the diversity of the population of the country. Media houses are seen to cluster in and around cities and towns. The importance of the media in disseminating information for development cannot be over emphasized. Rivers and Schramm (1969: p.2) comment on the ubiquitous nature of the mass media. In other words, "We have become aware of the importance of mass communication. Nearly everyone is convinced that the mass media, good or bad are central to modern society. Most of us depend upon mass communication products for a large majority of all the information and entertainment we receive during life." Annan (1997: p. 22) avers saying, "If information and knowledge are central to democracy, they are the conditions of development. Knowledge and information are essential for people to successfully respond to the opportunities and challenges of social, economic and technological changes. But to be useful, knowledge and information must be effectively communicated to people (World Bank, 2004: P. 5). Amodu (2007) cited in Anaeto (2010: p. 4) in examining development, says that it is the process of positive socio-economic change in the quality and level of human existence which is aimed at raising the standard of living, the quality of life and human dignity. Focusing on social needs, selfreliance and people's participation, Sanda (1992: p.107) defines development as being conceived as multidimensional referring to positive changes which affect the majority and which lie in the social, economic, political and cultural spheres of societal life...Development entails social progress in both economic and noneconomic components of societal life. Okigbo (1983: p. 26) and Harande (2009: p. 3) much earlier posits that national development is a process through which a polity improves its standard of living not only materially but also the realm of its value system, and that the development of countries globally cannot be achieved without the development of the rural community. Edeani (1993: p. 123) supports this position that rural development ...holds the key to national development because of a number of reasons. First, because of the enormous size of the rural population as compared to the small percentage living in the cities; Also, because of the very large 
share of the country's natural resources located in rural areas, and because of the disproportionate role which the rural population plays in the economic, rural and political life of the nation. Sanda (1997: p. 32) further declares that for development to take place several factors have to come into play including management, resources, culture, technology, information and not the least of which is communication.

The concept of using the communication media to bring about development is not a novel idea and has brought about paradigms and theoretical constructs over the years. United States Agency for International Development, USAID, (1984) states that the purposeful application of media and communication support ....has been subsumed under the larger movement normally referred to as Development Support Communication (DSC), or Development Communication. The term "Development Communication" was first coined in 1972 by Nora C. Quebral, who defines the field as "the art and science of human communication linked to a society's planned transformation from a state of poverty to one of dynamic socio-economic growth that makes for greater equity and the larger unfolding of individual potential." As broadly defined by the USAID $(1984$, p. i), the process of development communication refers to "the application of existing communication technologies and media to the problems of development." Coldevin (1987, p. 11) elaborately defines the concept of Communication for Development otherwise known as Development Communication as the systematic utilization of appropriate communication channels and techniques to increase people's participation in development and to inform, motivate, and train rural populations, mainly at the grassroots level."

Development Communication is a tool used to achieve national development in a country. National development, according to Sobowale,

is a functional and orderly transformation of a people's way of life: a transformation that arises from a conscious and recognized need to change familiar beliefs, attitudes and old ways of attaining goals in favour of more dynamic and efficient methods that enable a people to take full advantage of the benefits that such aids to communication as technology, interpersonal contacts and travel afford.

Teheranian (1977: p. 46) postulates on the effect of the media on national development saying, "the effect of the media in the process of national development depends vitally on how closely the media work with or against opinion leaders in safeguarding traditional ideas and institutions or pioneering new ones." $\mathrm{He}$ underscores the importance of communication to rural development. According to him, "Increased communication may mobilize minority ethnic groups who were once relatively indifferent to politics but who have now acquired national consciousness and demand a hearing on a par with the dominant national group."

Khadar and Ndiaye (1983: p. 6) declare that the general use of the print media in development is to provide information, to sensitize, reach and stabilise groups of rural people. Compared to other media, print has the advantage of being relatively cheap, as well as better to memorize because of the fact that written words or pictures stick better in mind. This medium is comparatively low-priced and available for a wide range of people. However despite the perceived role of the media in bringing about positive change, Sobowale maintains that the media since independence have remained largely urban in orientation and content. Folarin (2005: Ch. 5) makes a valid point that the New International Information and Communication Order, NWICO should begin in Nigeria by reducing the glaring imbalance of the flow of information between the majority rural and minority urban peoples. Sobowale asserts that with increased communication of the rural areas, the locus of news would of necessity have shifted from the cities and towns to the villages and hamlets. Those in the cities would thus be able to gain a better understanding of the people in the villages while the latter would be afforded an appreciation of the difference between their lifestyles and those of the urban dwellers. This would of course promote national development which cannot occur without rural development.

\section{Statement of Problem}

Rivers and Schramm (1969: p.14) submit that, most of a newspaper is designed to inform. John Bittner (2005: p.22) propose that newspapers are a major force in forming public opinion and affecting national and international efforts toward economic progress and global understanding. Moemeka (2005: Ch. 4) makes a welcome distinction between mass media used as vehicles of communication and mass media used as channels of information. He argues that the distinction is necessary because contrary to popular and sometimes professional opinion, mass media are not by nature channels of mass communication. They are merely channels of mass information, distribution and transmission. It is only when the mass media have been changed from acting as channels for distribution and transmission to asserting themselves as vehicles for participation, expression and discussion, he argues, that they can rightly be called the media of mass communication and can become effective in inducing culture-bound rural inhabitants to change their attitudes to life by accommodating new ideas.

Building on the framework of the Magic Bullet Theory Yahaya (2009: p. 49) however indicates that media practitioners as sources of information and mobilization for improved agricultural practices are not favourably predisposed to coverage of rural development news including agriculture given the media 
environment they operate. He states further that it is evidently clear that we are faced with scantiness of agricultural and rural development information in Nigerian media. It is on this note that this study is aimed at ascertaining the extent of newspapers' reportage of rural development because it has positive or negative implications for national development because as suggested earlier by Edeani, rural development holds the key to national development because it holds the majority of the population, it holds a large percentage of a nation's resources and because of the disproportionate role the rural population plays in the economic, rural and political life of a nation. Okiy (2003:p.1) says, "Rural development is a basis for economic development and information is an important ingredient in development process.

Diso (1994: p.143) holds the view that" information must as a matter of policy, be seen as a basic resource for development if durable structures are to be provided for effective access and utilization, which entails information capturing, coordination, processing, and dissemination". If information is a basic resource for development, the media as information providers can also be seen as a basic resource for development. Therefore, this research seeks to address the problem of the role the newspapers play in rural development, how socially responsible their position is in reporting rural matters, if it is in a bid to fill the newspaper pages or achieve actual development.

\section{Research Questions}

formulated:

With a view to finding solutions to the problems of this research, the following questions were

1. To what extent did the selected newspapers carry rural development stories within the period of this study?

2. In what proportions were journalistic genres used by the selected newspapers for the reportage in the selected newspapers?

3. Did the reportage vary in prominence, depth of treatment and point sizes?

4. How socially responsible was the reportage?

\section{Objectives of the Study}

On the basis of the research questions above, this study is set to widen the frontiers of knowledge. The objectives of this study are to:

1. Examine the quantity of coverage of rural development during the period of study.

2. Ascertain how editorial items and journalistic materials were used in reporting rural development stories.

3. Determine the importance attached to the reports in the selected newspapers and also determine what story approaches in which the coverage of rural development stories appeared more often.

4. Produce a manual for journalists and media professionals among others on how the press in Nigeria should report rural development in a socially responsible manner.

\section{The Scope of Study}

Every research work has its limitations and this particular research puts up no difference. This study concentrated on how rural issues in Nigeria were covered by Nigerian newspapers. It examined news coverage of rural agriculture, rural culture, rural education, rural infrastructure development, rural politics and, rural health and nutrition in selected newspapers. Four newspapers were selected for the study- Nigerian Tribune, Punch, The Guardian, and Daily Sun newspapers.

Nigerian Tribune is an independent newspaper published in Nigeria. It was established in November, 1949 by late Chief Obafemi Awolowo and is the oldest surviving private newspaper in Nigeria. It is based in Ibadan. Over the past 63 years, it has evolved to be one of Nigeria's top newspapers. Nigerian Tribune newspaper as observed by Nigerian newspapers. com provides an independent perspective with a commitment to credible dissemination of editorial information. It prides itself in providing its readers with cutting edge information and news, by keeping up with the latest developments.

The Punch is a private national newspaper based in Lagos. It was established by Late Chief Olu Aboderin. It has been rated the most widely read newspaper in Nigeria, with the highest circulation in Nigeria. The newspaper covers both local and international news.

The Guardian is a private Nigerian newspaper based in Lagos that is committed to promoting true democracy and individual freedom. It was established by the Ibru family and has since been committed to provide unbiased news coverage.

Daily Sun is a relatively new newspaper on the Nigerian newspaper scene. It made its debut on January 18, 2003 and was initially published as a weekly newspaper, but became a daily newspaper on June 16, 2003. It is among Nigeria's top producing and top selling newspapers.

There was a strong reason behind the choice of the four newspapers. It is essential to note that rural communities form a larger percentage of Nigeria's population than the urban populace, and hence, rural development becomes pivotal to any national developmental effort in the country. Therefore, the need for 
reportage of rural matters becomes a national issue. Consequently, newspapers to be chosen in this respect have to be national in their spread and circulation. This serves as the basis for the choice of the newspapers, which are rated as national newspapers by the Audit Bureau of Circulation (ABC), Nigerian Guild of Editors (NGE), and Nigerian Press Council (NPC).

\section{Review of Literature and Theoretical Framework}

Amodu (2007) cited in Anaeto (2010: p. 4) in examining development, says that it is the process of positive socio-economic change in the quality and level of human existence which is aimed at raising the standard of living, the quality of life and human dignity. Focusing on social needs, self-reliance and people's participation, Sanda (1992: p.107) defines development as being conceived as "multi-dimensional referring to positive changes which affect the majority and which lie in the social, economic, political and cultural spheres of societal life... Development entails social progress in both economic and non-economic components of societal life." Inayatullah (1967) as cited by Jimoh (2008: p. 105) defines development as the ability of man to have greater control over his environment and increased realization of its human values, its political destiny and self discipline. Here, he emphasizes human indices as better management and control of the environment, including the need for good political system of governance which is acceptable to all. This is the realm of sustainable development. That is, developing without destroying the environment. Inayatullah also emphasized the endogenous path to development through the participatory approach. This will help in sustaining the values of the people.

Participation by the people for development programs and policies is a major impetus for development. Similarly, in a precise but all encompassing definition of development, the duo of Melkote and Steeves (2001:45) simply define development as "the process by which societal conditioning are improved." Development is also understood on the basis of a renewed thinking on sustainable development "as the increasing capacity of man to manipulate his environment to his betterment." (Jimoh, 2005: p.1) All efforts both physical and social including policies and programs geared towards a better life for the people excluding politics and political activities will be seen as development oriented. Better life is seen in line with Sears' (1977: p. 124) conceptualization of development as:

the questions to ask about a country's development are therefore; what has been happening to poverty? What has been happening to unemployment? What has been happening to inequality? If all three of these have declined from high levels, then beyond doubt this has been a period of development for the country concerned. If one or two of these central problems have been growing worse, especially if all three have, it would be strange to call the result 'development' even if per capita income doubled.

Clearly, Sears contention is that social indices of reduction in poverty, unemployment and inequality are better yardsticks for measuring the development status of a nation. Reason being that high economic indices do not translate to better life and sometimes may worsen it as the state of inequality may increase. In the same vein, Young (1993) cited in Lanihun in Soola (2002: p. 75) avers that: "development implies a change for the better: the ordering of society and social and economic processes in such a way as to lead to the eradication of gross poverty, ill-health, and illiteracy and to rising standards of living and increased material comforts for all."

These additional human indices of good health, improved literacy levels to eradication of poverty, unemployment and inequality constitute this study's understanding of development. Indeed even the millennium development goals of eradication of extreme poverty and hunger; achieving universal primary education; promoting gender equality and empowerment of women; reduction of child mortality; improvement of maternal health; combating HIV/AIDS, malaria and other diseases; ensuring environmental sustainability; and developing global partnership (Millennium Development Goals Report 2004) are rooted in these indicators of development. Oso and Adebayo(1990: p. VIII) assert that "within the context of promoting development, and in this instance rural development, information dissemination assumes a specific role, that of mediating to promote development." The media are to play a major and direct role as magic multiplier of both the diffusion process and the resultant development benefits.

In the struggle for national development, according to Moemeka (1990: p. 72),

The uneducated and impoverished rural majority cannot be left out without devastating consequences In the effort to enlist their contribution, the mass media cannot be ignored, and in the attempt to use these media of mass communication to liberate, enlighten and educate rural people for development, the strategy should be one which gives priority to the aims of not mere information distribution and transmission but of participation, expression and communication.

\section{According to Oso,}

Mass media are the great teachers and mobilizer for change. They are to mobilize human resources by substituting new norms and values, attitudes and behavior for existing new ones in order to stimulate the rural 
dwellers to increase their productivity and its the value that support this ideology of hard work that...In a broad sense, the mass media serve to maintain and perpetuate the prevailing ideology.

Communication plays a vital role in development. This assertion was made by Harrison (p. 4), "the spread of the mass media has been among the most powerful forces for social change in developing as well as in developed countries. The media have broadened narrow horizons, accelerated the pace of transformation and created a climatic readiness for development." In Africa, mass media contents are generally dominated by political and other non-development oriented reports. Barton (1979) found that the content of the press was largely on political matters with little attention paid to the development needs of Africa. He argued that this may be due to the fact that the press of Africa was founded on the basis of nationalism and politics. Barton's work though comprehensive is limited in context and time. The study was conducted in 1970s when Nigeria was under military era, which may have affected press coverage of development matters. Malam (2005) found in a content analysis study of five newspapers including Gaskiya Tafi Kwabo, that:

Irrespective of such factors as ownership, scope of circulation and head office location, all the papers separately and collectively had an average of $85 \%$ of their stories focused on urban oriented activities; $6 \%$ rural and $8 \%$ both (e.g. elections or natural disasters).

\section{Newspaper and Rural Development}

Based on this understanding of development, some nations are developed while others are not. The high level of poverty, unemployment, poor health conditions, inequality between the haves and have-nots in Nigeria are clear indicators that Nigeria is an under-developed nation. The rural people of the country are worse off by these yardsticks. The result is that poverty, hunger, diseases etc are much more pronounced in the rural areas than those of the urban centres. Anaughe \& Okwudiafor (1987: p. 9) see rural development as "being concerned with any method used in raising the quality of life of the low income population living in rural areas on a self-sustaining basis through a fundamental transformation of the rural mode of production."

For rural development to be achieved, the press has a role to play. This can come in the form of passing information about a nation's development opportunities for change, method and means of achieving possible change (Schramm, 1964).The need for rural mobilization as a countervailing force for development calls for formation, at the grassroots, of strong organization capable of articulating and protecting the interests of the local (rural) populace. Such grassroots voice has the capacity not only to draw attention to itself but also to force the central authorities to enter into a negotiated relationship with the rural communities. Melkote (1991:201) as cited in Soola (2003: p. 15) cited Uploff and Esman as underscoring the imperatives of rural local organization, stating that,

Those cases in which there were more organizations reaching down to the local level, accountable to the local people, and involved with rural development functions have accomplished rural development objectives more successfully with respect to the available resource base than have those with less rural organization.

The need for a cautious application of the media is informed by its potential both to serve as a catalyst and to act as a drag in the wheel of development and progress. The mass media according to Fair and Shah (1997: p. 25), rather than being purveyors of progress and a means of overcoming development, can infact, just be one more cause of underdevelopment in that they may serve not only to reinforce but also to perpetuate existing power relations and structures of inequality. The general use of print media in development is to provide information, to sensitize, reach and stabilise groups of rural people. Compared to other media, print has the advantage of being relatively cheap, as well as better to memorize because of the fact that written words or pictures stick better in mind. This medium is comparatively low-priced and available for a wide range of people. The newspaper which is classified under the print media has enduring characteristics which neither the radio nor television has. The newspaper, according to Moemeka (1990: p. 63).

Can be read and re-read at convenience thus allowing for fuller and better understanding of message contents. It can be stored away for future use, thus, making for the presentation of materials that are considered important for future reference. They are also capable of carrying literacy and non-formal education materials and of serving as reading materials for new literates,, thus ensuring that illiterates do not only learn to read but also read to learn.

Newspaper publication started in Nigeria in 1859 and today, there are quite a number of government and privately -owned newspapers in the country varying in frequency and time of publication as well as circulation rate, target audience and achievements. One of the primary functions of the newspaper is to objectively report news situation or events in all fields of human endeavour. Usually, management of the print media assesses the newsworthiness of events and based on the philosophy and interests of the organization, takes the decision on how best to present or showcase news events to achieve maximum effect. According to Hoslti (1969: p. 53), it also serves the purpose of describing trends in communication, analyzing techniques for persuasion, and relating known attributes of the audience to messages produced for them 
Bittner (2005:22) opines that newspapers are a major force in forming public opinion and affecting national and international efforts toward economic progress and global understanding.

Williams (1978: p. 471-472) states that,

with the power of publicity, promotion and with a knowledge of existing conditions, the newspaper is in a better position than any other organization in the community to acquaint the general public with its needs and possibilities and to show how these needs may be met.

Agee (1979: p. 201) saw the need for simplicity when he suggested that "if newspapers are to fulfill their role of communication to the mass of the population they cannot indulge in writing styles and terminology so involved that many readers cannot comprehend." Effective communication with the rural population would be impossible "unless the communicator enters into cultural context of the people and understands at first hand their economic and social peculiarities." Moemeka (1990: p. 67). According to Akeju (1988), among other information needed by rural dwellers is information for increased productivity and income growth, information for social participation and political involvement. For effective rural development, according to Fakunle (1992: p. 5-6) the rural dwellers therefore need to be provided with information on the following:

\section{Health Service}

Rural dwellers need information on first aid treatment and rural health education. Rural dwellers need to be educated and provided with information on how to improve the quality, value and nutritional balance of their food. They need to be enlightened on how diseases could be prevented and what to do when there is an epidemic.

\section{Agricultural Activities}

Farming is a major occupation of rural dwellers. Farmers in the rural areas need information and enlightenment on how they could complement the traditional farming system with the modern practice.

\section{Political programmes}

With the current political dispensation which put emphasis on the grassroots' participation, the rural dwellers need to be enlightened and integrated into the political process. The significance of every stage of the political process need to be explained to the rural dwellers with the role they are expected to play in order to install a purposeful and responsive government.

\section{Infrastructural development}

One of the major problems in the rural communities is insufficient funds to execute projects for communal purposes. The rural dwellers need information on how they can pull their money together to fund individual or community projects.

\section{Methodology}

This study employed a combination of two research methods that are considered most appropriate namely, content analysis and the dialectical hermeneutical style of textual analysis. McQuail (2005: p. 76) describes content analysis as "a technique for the systematic, quantitative and objective description of media texts, that is useful for certain purposes of classifying output, looking for effect and making comparisons between media over time or between content and reality." Therefore, this method was adopted to measure the quantity of the reportage of rural issues by the newspapers and also determine the prominence given to the issues by the newspapers. The dialectical hermeneutics method of textual analysis was also used to subject the contents of the newspapers regarding rural issues to discursive analysis and interpretation so as to investigate and ascertain the extent of social responsibility displayed by the newspapers..

\section{Content Categories}

According to Berelson (1952: p. 147), content analysis stands or falls by its categories. The content analyst aims at a quantitative classification of a given body of content, in terms of a system of categories devised to yield data relevant to specific hypotheses concerning that content (Kaplan and Goldsen, 1943: p. 1).The formulation and the definition of appropriate categories take on central importance. Berelson (1952: $\mathrm{p}$. 147) said that since the categories contain the substance of the investigation, a content analytical research can be no better than its system of categories. It was for this reason that the following content categories were formulated to analyze the content and serve as an instrument for addressing the problem of the study.
1. Rural development oriented stories
a) Agricultural development stories
b) Cultural stories
c) Education stories 
d) Infrastructure development stories

e) Health and nutrition stories

f) Political stories

The above content categories were analyzed using the following:

1. Newspaper Identity

1) Nigerian Tribune (NIT)

2) Punch (PUN)

3) The Guardian (THG)

4) Daily Sun (DAS)

2. Type of Story

1) Straight news story

2) Feature

3) Editorials

4) Opinions/Columns

3. Placement of Stories

1) Front page

2) Back page

3) Centre spread

4) Inside page

4. Length of Story

1) 1-4 paragraphs

2) 5-8 paragraphs

3) 9-12 paragraphs

4) 13-16 paragraphs

5) 17 and more paragraphs

5. Point sizes

1) $18-24$

2) $36-48$

3) $54-60$

4) 72 and more

\section{Population of the Study}

The population of the study consisted of all the editions of the Nigerian Tribune, the Punch, the Guardian, and the Daily Sun newspapers published in Nigeria within the period of January 2009 to December 2011.

\section{Sampling Technique}

Bello and Ajayi (2000: p. 38) posit that 'sampling is a systematic process used to select a required portion of a target population. In any research, a representative sample of a population is that sample which has approximately the characteristics of the population relevant to the research under investigation'. Trochim (2006: p. 97) defines sampling as the process of selecting units (e.g., people, organizations) from a population of interest so that by studying the sample we may fairly generalize our results back to the population from which they were chosen. Purposive sampling technique was used to select the newspapers that will represent the population. Purposive sample according to Tejumaiye (2003: p. 37) is a sample selected on the basis of specific characteristics or qualities and elimination of those that fail to meet these criteria. It is deliberately chosen and is based on the researcher's judgment. Nworgu (1991:78) corroborates this statement, saying: "Although the criteria to be used are usually a matter of the researcher's judgment, he exercises this judgment in relation to what he thinks will constitute a representative sample with respect to the research purpose."

\section{Sample Size}

From the selected newspapers, forty editions of each was randomly selected. With the forty editions divided into twenty for each year of the period of study. Subsequently, a total of 160 editions were analyzed for this study.

\section{Presentation and Discussion of Findings}

The purpose of this study was to ascertain the extent of reportage of rural development by selected newspapers. In order to provide answers to the research questions raised in the study, some of the data collected during the course of the study were computer analyzed using the Statistical Package for Social Sciences (SPSS) 
format while some others qualitatively analyzed using textual analysis. The findings are presented and discussed with a view to making deductions and drawing a conclusion.

Table 1 shows the total number of newspapers that were content analyzed and the rural development oriented categories for each selected newspaper. A total of 160 editorial items from 95 editions of the selected

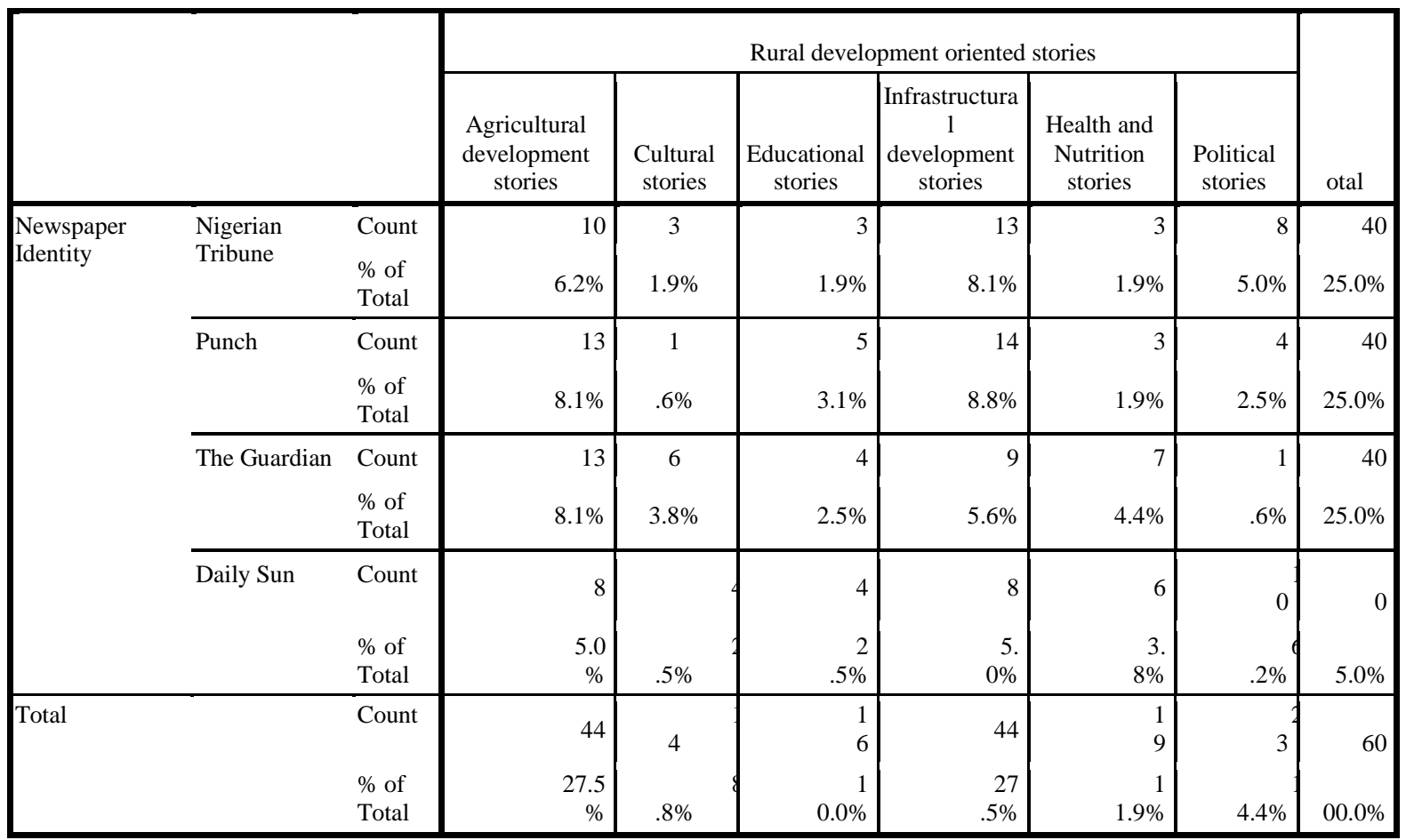

newspapers were content analyzed. Distributing these issues, 40 of them were in Nigerian Tribune, 40 in Punch, 40 in The Guardian, and 40 in Daily Sun. The table also shows the distribution of stories published by selected newspapers.

\section{Table 1 Distribution of Newspapers}

\section{Research Question 1}

To what extent did the selected newspapers carry rural development stories within the period of this study?

The above question examines the quantity of the reportage of rural development stories in the categories of agricultural development stories, cultural stories, educational stories, infrastructural development stories, health and nutrition stories and political stories. This is important in considering the paradigm that the media are capable of engendering rural development and in connection national development based on the way and manner in which they report such stories .Out of a total of forty (40) stories published by the Nigerian Tribune newspaper, ten stories, six point two per cent $(6.2 \%)$ were considered as representing agricultural development in rural Nigeria. Three stories, One point nine (1.9\%) were considered as representing culture in rural Nigeria. Three stories, One point nine $(1.9 \%)$ were considered as representing educational issues in rural Nigeria. Thirteen stories, eight point one per cent $(8.1 \%)$ were considered as representing rural infrastructural development. Three stories, One point nine $(1.9 \%)$ were considered as representing rural health and nutrition issues. Eight stories, five per cent $(5.0 \%)$ were considered as representing rural politics in Nigeria. Out of a total of forty (40) stories published by the Punch newspaper, thirteen stories, eight point one (8.1\%) were considered as representing agricultural development in rural Nigeria. One story, zero point six per cent $(0.6 \%)$ were considered as representing culture in rural Nigeria. Five stories, three point one per cent $(3.1 \%)$ were considered as representing educational issues in rural Nigeria. Fourteen stories, eight point eight per cent $(8.8 \%)$ were considered as representing rural infrastructural development. Three stories, One point nine (1.9\%) were considered as representing rural health and nutrition issues. Four stories, two point five per cent $(2.5 \%)$ were considered as representing rural politics in Nigeria. Out of a total of forty (40) stories published by the Guardian newspaper, thirteen stories, eight point one $(8.1 \%)$ were considered as representing agricultural development in rural Nigeria. Six stories, three point eight per cent $(3.8 \%)$ were considered as representing culture in rural Nigeria. Four stories, two point five per cent $(2.5 \%)$ were considered as representing educational issues in rural Nigeria. Nine stories, five point six per cent $(5.6 \%)$ were considered as representing rural infrastructural development. Seven stories, four point four per cent $(4.4 \%)$ were considered as representing rural 
health and nutrition issues. One story, zero point six per cent $(0.6 \%)$ were considered as representing rural politics in Nigeria. Out of a total of forty (40) stories published by the Daily Sun newspaper, eight stories, five per cent $(5.0 \%)$ were considered as representing agricultural development in rural Nigeria. Four stories, two point five per cent $(2.5 \%)$ were considered as representing culture in rural Nigeria. Four stories, two point five per cent $(2.5 \%)$ were considered as representing educational issues in rural Nigeria. Eight stories, five per cent $(5.0 \%)$ were considered as representing rural infrastructural development. Six stories, three point eight per cent (3.8\%) were considered as representing rural health and nutrition issues. Ten stories, six point two per cent $(6.2 \%)$ were considered as representing rural politics in Nigeria.

Therefore, the majority of rural development oriented news stories published by the Nigerian Tribune in the period of this study were on infrastructural development. Similarly, the Punch, out of a total of forty stories, fourteen stories (8.8\%) majority were on infrastructural development. In the case of The Guardian, thirteen $(8.1 \%)$ out of forty stories published by the newspaper which represents the majority were on agricultural development. Daily Sun published a majority of ten stories $(6.2 \%)$ which represented the majority was on politics. In all, agricultural stories accounted for twenty seven point five per cent (27.5\%) of reports by the five newspapers. Infrastructural development stories also accounted for twenty seven point five per cent (27.5\%) of reports by the five newspapers. This suggests that agricultural development stories and infrastructural development stories were the most reported by the selected newspapers. Cultural stories accounted for the least coverage by the selected newspapers with eight point eight per cent (8.8\%).

Therefore it is concluded in this study that the selected newspapers specifically devoted a considerable percentage of their reports to agricultural development and infrastructural development stories. Owing to the fact that cultural stories amount for the least percentage of coverage by the selected newspapers, it is being posited here that there is a need for more attention to be paid to that category of rural development.

\section{Research Question 2}

In what proportions were journalistic genres used by the selected newspapers for the reportage in the selected newspapers?

The question is directed towards examining how the various journalistic genres were used by the various newspapers for rural development oriented stories in Nigeria.

Table 2 Distribution of Journalistic Genres for The Reportage

\begin{tabular}{|c|c|c|c|c|c|c|c|}
\hline & & & \multicolumn{4}{|c|}{ Type of story } & \multirow[b]{2}{*}{ otal } \\
\hline & & & $\begin{array}{r}\text { Stra } \\
\text { ight news story }\end{array}$ & $\begin{array}{l}\mathrm{Fe} \\
\text { ature story }\end{array}$ & ditorial & $\begin{array}{r}\text { Opi } \\
\text { nions/Columns }\end{array}$ & \\
\hline \multirow[t]{8}{*}{ Newspaper Identity } & Nigerian Tribune & Count & 26 & 13 & 0 & 1 & 40 \\
\hline & & $\%$ of Total & $16.2 \%$ & $8.1 \%$ & $.0 \%$ & $.6 \%$ & $25.0 \%$ \\
\hline & Punch & Count & 36 & 4 & 0 & 0 & 40 \\
\hline & & $\%$ of Total & $22.5 \%$ & $2.5 \%$ & $.0 \%$ & $.0 \%$ & $25.0 \%$ \\
\hline & The Guardian & Count & 27 & 12 & 1 & 0 & 40 \\
\hline & & $\%$ of Total & $16.9 \%$ & $7.5 \%$ & $.6 \%$ & $.0 \%$ & $25.0 \%$ \\
\hline & Daily Sun & Count & 25 & 10 & 0 & 5 & 40 \\
\hline & & $\%$ of Total & $15.6 \%$ & $6.2 \%$ & $.0 \%$ & $3.1 \%$ & $25.0 \%$ \\
\hline \multirow[t]{2}{*}{ Total } & & Count & 114 & 39 & 1 & 6 & 160 \\
\hline & & $\%$ of Total & $71.2 \%$ & $24.4 \%$ & $.6 \%$ & $3.8 \%$ & $100.0 \%$ \\
\hline
\end{tabular}

The results show that seventy one point two per cent $(71.2 \%)$ of all the stories by the selected newspapers were in the straight news format. Twenty four point four per cent $(24.4 \%)$ of all the stories in the selected newspapers were in the feature format. Zero point six per cent $(0.6 \%)$ of all the stories were the editorial genre. Three point eight per cent (3.8\%) of all the stories were in the opinion/column format. All the selected newspapers made use of the straight news format most often than the other genres. This was followed by features and opinions/ columns. Consequently, the straight news format was used most often by the selected newspapers serves as an informative channel only as required of the genre. Feature, where in depth analysis is requirement, was utilized but not as much as the straight news genre. 


\section{Research Question 3}

Did the reportage vary in prominence, depth of treatment and point sizes?

This multi-dimensional question delves into the nature of reporting on rural development by the various selected newspapers by specifically examining attributes of the reports published by these papers. These attributes involve the placement of the story (as a means of determining the prominence conferred upon an issue or a story), length/depth of the story and the point size used for headlines that were cast for the stories. The question is directed to gaining a wholesome view of the reportage of rural development by the various newspapers through a thorough examination using a number of different parameters.

\section{Placement of Stories}

In terms of positioning, it is normally expected that majority of stories should be on the inside pages because the front and back pages provide limited space and are used to feature the most important news items. Similarly, the bulk of stories published by the four newspapers fell into the inside page category.

Table 3 CROSS TABULATION OF NEWSPAPERS AND PLACEMENT OF STORY

\begin{tabular}{|c|c|c|c|c|c|c|}
\hline & & & \multicolumn{3}{|c|}{ Placement of stories } & \multirow[b]{2}{*}{ otal } \\
\hline & & & $\mathrm{t}_{\text {page }}{ }^{\text {Fron }}$ & $k_{\text {page }}{ }^{\mathrm{Bac}}$ & page ${ }^{\text {Inside }}$ & \\
\hline \multirow[t]{8}{*}{ Newspaper Identity } & Nigerian Tribune & Count & 0 & 0 & 40 & 40 \\
\hline & & $\%$ of Total & $.0 \%$ & $.0 \%$ & $25.0 \%$ & $25.0 \%$ \\
\hline & Punch & Count & 0 & 0 & 40 & 40 \\
\hline & & $\%$ of Total & $.0 \%$ & $.0 \%$ & $25.0 \%$ & $25.0 \%$ \\
\hline & The Guardian & Count & 1 & 2 & 37 & 40 \\
\hline & & $\%$ of Total & $.6 \%$ & $1.2 \%$ & $23.1 \%$ & $25.0 \%$ \\
\hline & Daily Sun & Count & 1 & 0 & 39 & 40 \\
\hline & & $\%$ of Total & $.6 \%$ & $.0 \%$ & $24.4 \%$ & $25.0 \%$ \\
\hline \multirow[t]{2}{*}{ Total } & & Count & 2 & 2 & 156 & 160 \\
\hline & & $\%$ of Total & $1.2 \%$ & $1.2 \%$ & $97.5 \%$ & $100.0 \%$ \\
\hline
\end{tabular}

Table 3 shows that ninety seven point five per cent $(97.5 \%)$ of all stories by the selected newspapers were placed on inside pages. One point two per cent $(1.2 \%)$ of the stories were placed on front pages. One point two per cent $(1.2 \%)$ of the stories were placed on back pages. This means that almost all the stories were placed on inside pages and marginal percentages of the stories were placed on the front and back pages. Twenty five per cent $(25 \%)$ of all the stories by the Nigerian Tribune newspaper were on the inside pages which constituted the whole of all the stories analyzed. This means that there were no rural development stories published on the front, back and centre pages. Similarly, Twenty five per cent $(25 \%)$ of all the stories by the Punch newspaper were on the inside pages which constituted the whole of all the stories analyzed. This means that there were no rural development stories published on the front, back and centre pages. In the case of the Guardian newspaper, zero point six per cent $(0.6 \%)$ of all the stories were placed on the front page, one point two per cent $(1.2 \%)$ were placed on the back page and twenty three point one per cent of all the stories which constitutes the vast majority were placed on the inside pages, with none of the stories placed on the centre pages. In the case of the Daily Sun newspaper, zero point six per cent $(0.6 \%)$ of all the stories were placed on the front page, none of the stories were placed on the back or centre pages, while twenty four point four per cent $(24.4 \%)$ of all the stories were placed on the inside pages. These results indicate that only The Guardian and Daily Sun newspapers considered rural development news important enough to be placed on the front pages of their newspapers. The Guardian newspaper was the only newspaper to publish rural development news on the back page. The Nigerian Tribune and The Punch place any prominence on rural development stories as none of the stories were placed on the front, back, or centre pages. Consequently, by way of general placement of stories, the newspapers gave less prominence to rural development stories by placing the majority of the stories on inside pages.

\section{Depth of Treatment}

This refers to the length of a news story and this was measured in paragraphs. The depth is an important attribute and bestows a certain degree of importance on an issue, considering that increased length often entails more extensive or in depth treatment of an issue or event unlike obtained in short stories i.e. 
straight news stories where space may only permit inclusion of the very necessary details with no description, explanation or interpretation.

Table 4 Distribution of Newspaper by Depth of Story

\begin{tabular}{|c|c|c|c|c|c|c|c|c|}
\hline & \multicolumn{5}{|c|}{ Length of story } & \multirow[b]{2}{*}{ otal } \\
\hline & & & $\begin{array}{c}1-4 \\
\text { paragraphs }\end{array}$ & $\begin{array}{c}5-8 \\
\text { paragraphs }\end{array}$ & $\begin{array}{c}9-12 \\
\text { paragraphs }\end{array}$ & $\begin{array}{c}13-16 \\
\text { paragraphs }\end{array}$ & $\begin{array}{l}17 \text { and more } \\
\text { paragraphs }\end{array}$ & \\
\hline \multirow{8}{*}{$\begin{array}{l}\text { Newspaper } \\
\text { Identity }\end{array}$} & \multirow{2}{*}{$\begin{array}{l}\text { Nigerian } \\
\text { Tribune }\end{array}$} & Count & 6 & 21 & 6 & 2 & 5 & 40 \\
\hline & & $\begin{array}{l}\% \text { of } \\
\text { Total }\end{array}$ & $3.8 \%$ & $13.1 \%$ & $3.8 \%$ & $1.2 \%$ & $3.1 \%$ & $25.0 \%$ \\
\hline & \multirow[t]{2}{*}{ Punch } & Count & 4 & 14 & 13 & 5 & 4 & 40 \\
\hline & & $\begin{array}{l}\% \text { of } \\
\text { Total }\end{array}$ & $2.5 \%$ & $8.8 \%$ & $8.1 \%$ & $3.1 \%$ & $2.5 \%$ & $25.0 \%$ \\
\hline & \multirow[t]{2}{*}{ The Guardian } & Count & 4 & 7 & 14 & 4 & 11 & 40 \\
\hline & & $\begin{array}{l}\% \text { of } \\
\text { Total }\end{array}$ & $2.5 \%$ & $4.4 \%$ & $8.8 \%$ & $2.5 \%$ & $6.9 \%$ & $25.0 \%$ \\
\hline & \multirow[t]{2}{*}{ Daily Sun } & Count & 2 & 13 & 11 & 2 & 12 & 40 \\
\hline & & $\begin{array}{l}\% \text { of } \\
\text { Total }\end{array}$ & $1.2 \%$ & $8.1 \%$ & $6.9 \%$ & $1.2 \%$ & $7.5 \%$ & $25.0 \%$ \\
\hline \multirow{2}{*}{\multicolumn{2}{|c|}{ Total }} & Count & 16 & 55 & 44 & 13 & 32 & 160 \\
\hline & & $\begin{array}{l}\% \text { of } \\
\text { Total }\end{array}$ & $10.0 \%$ & $34.4 \%$ & $27.5 \%$ & $8.1 \%$ & $20.0 \%$ & $100.0 \%$ \\
\hline
\end{tabular}

The above table shows the length/depth of stories published by the various newspapers. It is noted that this is a method through which news media attach prominence to their new stories. The findings of this research shows that ten per cent (10.0\%) of all news stories were as long as 1 and 4 paragraphs, 5 and 8 paragraphs accounted for thirty four point four per cent (34.4\%) of all news stories by the selected newspapers. 9 and 12 and 13 and 16 paragraphs accounted for twenty seven point five per cent $(27.5 \%)$ and eight point one per cent $(8.1 \%)$ respectively of all news stories in all the selected newspapers. Twenty per cent $(20 \%)$ of the news stories accounted for 17 and more paragraphs. This means that more than half of the stories were between 5 and 12 paragraphs. The table shows that news reports ranging from 1 and 4 paragraphs in length accounted for three point eight per cent $(3.8 \%)$ of stories published by the Nigerian Tribune newspaper, those between 5 and 8 paragraphs long and 9 and 12 paragraphs in length accounted for thirteen point one (13.1\%) and three point eight per cent $(3.8 \%)$ respectively of the newspaper's stories. Furthermore, one point two per cent $(1.2 \%)$ and three point one per cent $(3.1 \%)$ of the newspapers stories were 13 and16 paragraphs and 17 and more paragraphs in length. This indicates that majority of the rural development stories published by the Nigerian Tribune were within 5 and 8 paragraphs in length. Similarly, the Punch recorded two point five per cent $(2.5 \%)$ for stories within 1 and 4 paragraphs, eight point eight per cent $(8.8 \%)$ and eight point one per cent $(8.1 \%)$ accounted for news stories within 5 and 8 paragraphs and 9 and 12 paragraphs respectively in length. Furthermore, three point one per cent $(3.1 \%)$ and two point five per cent $(2.5 \%)$ of the newspapers stories were 13 and 16 paragraphs and 17 and more paragraphs in length.

This indicates that majority of the rural development stories published by the Punch were within 5 and 8 paragraphs in length. In the case of The Guardian, two point five per cent $(2.5 \%)$ represented stories within 1 and 4 paragraphs in length, four point four per cent $(4.4 \%)$ and eight point eight per cent $(8.8 \%)$ accounted for news stories within 5 and 8 paragraphs and 9 and 12 paragraphs respectively in length. Furthermore, two point five per cent $(2.5 \%)$ and six point nine per cent (6.9\%) of the newspapers stories were 13 and16 paragraphs and 17 and more paragraphs in length. This indicates that majority of the rural development stories published by the Guardian were within 9 and 12 paragraphs in length. Daily Sun recorded one point two per cent (1.2\%) for stories within 1 and 4 paragraphs in length, eight point one per cent (8.1\%) and six point nine per cent (6.9\%) accounted for news stories within 5 and 8 paragraphs and 9 and 12 paragraphs respectively in length. Furthermore, one point two per cent $(1.2 \%)$ and seven point five per cent $(7.5 \%)$ of the newspapers stories were 13 and 16 paragraphs and 17 and more paragraphs in length.

As in the case of Nigerian Tribune and the Punch, Daily Sun also has a majority of its stories between 5 and 8 paragraphs in length. Daily Sun newspaper has the largest percentage of stories longer than seventeen paragraphs, followed by the Guardian, Nigerian Tribune and the Punch newspapers. While Nigerian Tribune has the highest percentage of short stories. Therefore, this research advances that by the depth of reports analyzed, Daily Sun, and the Guardian gave rural development oriented stories mire prominence than the other 
newspapers. On the other hand, Nigerian Tribune and the Punch had the largest percentage of stories between 1 and 8 paragraphs, thus they had the largest portion of relatively short news stories and could be said to have given rural development stories less prominence than the other newspapers by way of depth of reports.

\section{Point Size}

Point size is an important parameter by which to judge and ascertain the measure of importance attached to any given news report by a newspaper. It refers to the size of lettering used in the headline of stories and is important, considering that greater size of font/ lettering often means more attention being drawn to a story more than others with smaller font sizes. Thus stories which the media consider as being more important than others on the same page often have headlines with relatively larger lettering, this is done to draw the attention of the reader first to such stories. Table 5 shows the font sizes of headlines used by the selected newspapers in reporting rural development stories as a measure of the importance they attached to the stories.

Table 5 Cross Tabulation of Point Sizes by Type of Newspaper

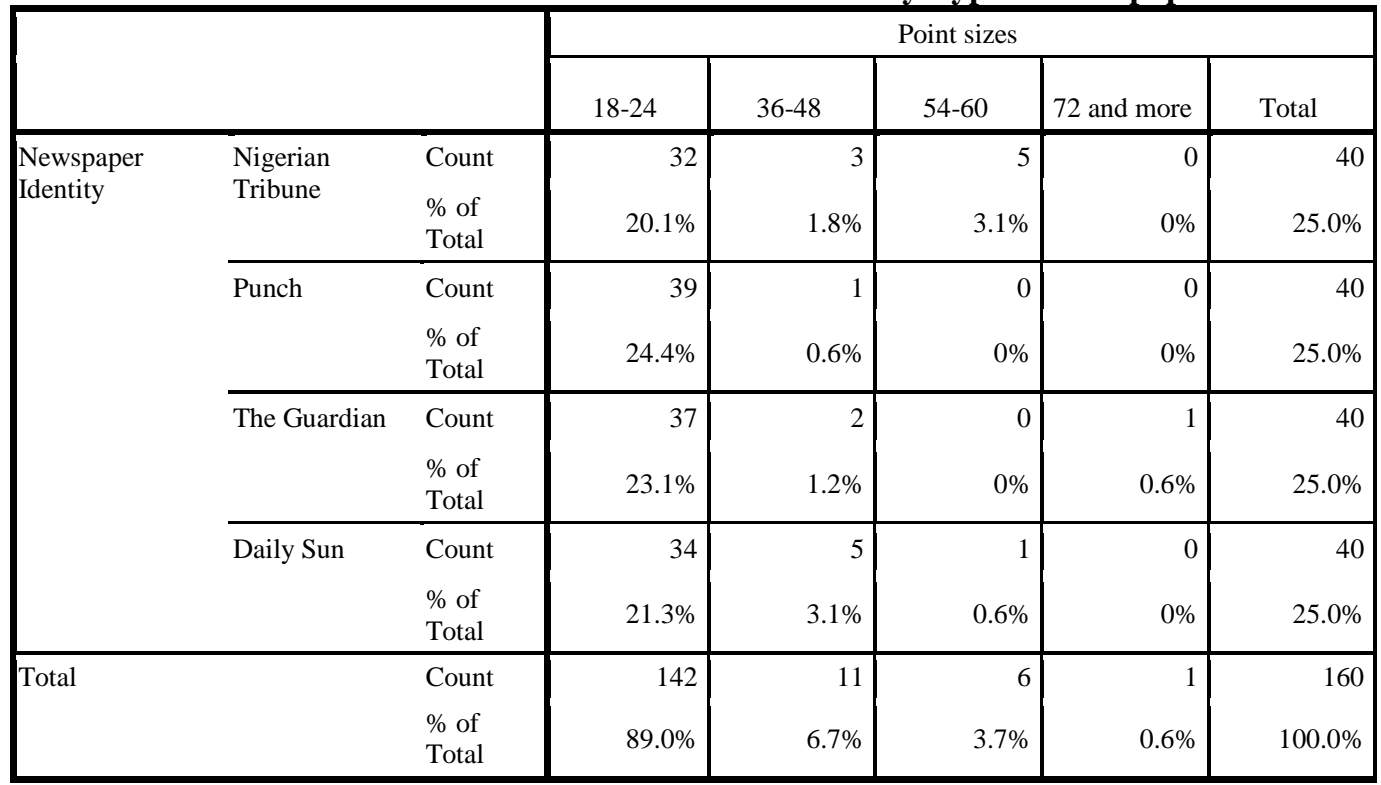

The table shows that eighty nine per cent $(89 \%)$ of all the headlines by all the selected newspapers were between 18 and 24 point size, six point seven per cent $(6.7 \%)$ were between 36 and 48 point, three point seven per cent $(3.7 \%)$ were between 54 and 60 point size and zero point six per cent $(0.6 \%)$ were larger than 72 points. This reveals that the bulk of the headlines used in all the newspapers were between 18- 24 points. This suggests that based on this parameter of adjudging importance the selected newspapers did not consider rural development oriented stories very important. The Nigerian Tribune shows that twenty point one per cent ( $20.1 \%)$ of all its headlines were between 18 and 24 point size, one point eight per cent $(1.8 \%)$ were between 36 and 48 point, three point one per cent (3.1\%) were between 54 and 60 point size and none of the headlines were larger than 72 points. This reveals that the Nigerian Tribune did not consider any rural development story important enough to use 72 point size and more. The bulk of its headlines fell between 18 and 24 points. Similarly, the Punch shows that twenty four point four per cent (24.4\%) of all its headlines were between 18 and 24 point size, zero point six per cent $(0.6 \%)$ were between 36 and 48 point, and none of the headlines were larger than 48 points. This reveals that the Punch did not consider any rural development story important enough to use 54 point size and above. The bulk of its headlines fell between 18 and 24 points. In the case of the Guardian, the table shows that twenty three point one per cent $(23.1 \%)$ of all its headlines were between 18 and 24 point size, one point two per cent $(1.2 \%)$ were between 36 and 48 point, none of the headlines were between 54 and 60 points and zero point six per cent $(0.6 \%)$ was larger than 72 points. This indicates that the Guardian considered rural development story important enough to use 72 point size and above for its major story of the day on the cover page. However, the bulk of its headlines fell between 18 and 24 points. Furthermore, twenty one point three per cent (21.3\%) of headlines by the Daily Sun were between 18 and 24 point size, three point one per cent $(3.1 \%)$ were between 36 and 48 point, zero point six per cent $(0.6 \%)$ of the headlines were between 54 and 60 points and none were larger than 72 points. This reveals that the Daily Sun did not consider any rural development story important enough to use 72 point size and more. The bulk of its headlines fell between 18 and 24 points. These results suggest that the Guardian gave the greatest measure of prominence followed by the Nigerian Tribune. On the other hand, the Punch had the highest percentages of 
headlines with pint size between 18 and 24, hence could be said to have given the least measure of prominence to rural development stories.

\section{Research Question 4}

How socially responsible was the reportage?

The dialectical hermeneutical style of textual analysis was used to investigate and determine this as indicated hereunder:

\section{NIGERIAN TRIBUNE}

\section{GASHAKA GUMTI NATIONAL PARK}

Gashaka Gumti National Park, the largest park in Nigeria, covers an area of wilderness greater than 6, 600 square kilometers. The park's name is derived from two of the region's oldest and most historic settlements: Gashaka village in Taraba state and Gumti village in Adamawa state. (August 12, 2009, page 19)

This story beams its light on the largest park in Nigeria that is located in the rural area. In this story, the media performs its role in publicizing a park located in the rural area thereby incoporating it into the cognitive system of the readers. In other words, Daily Champion, in a feature story sheds light on this rural entertainment area that has the capability of being a national entertainment park because despite the fact that it is named Gashaka Gumti National Park, it does not have a national outlook. The journalist achieved his aim in presenting the park in positive light by describing its history, features and attractions.

\section{OGUN COMMISSIONER SEEKS MAXIMIZATION OF FADAMA III}

The Ogun state Commissioner for Agriculture, Mr Tunji Akinosi, assured that the FADAMA III programme would increase the income of users of rural land and water resources on a sustainable basis, through the empowerment of communities to cater for their development agenda. (January 6, 2010, page 19)

This story highlights information from the Ogun state government assuring residents that the FADAMA III programme would be of developmental benefit to them. This story would serve as a reminder to other state governments not to neglect their rural communities, however, the audience that the story is to address might not have access to the story. The journalist sought to inform the public and succeeded in doing so by employing the straight news story format.

\section{AJIMOBI UNFOLDS PLAN TO REVAMP OYO ECONOMY}

Abiola Ajimobi listed the policy thrust of the new administration to include human capital development, which would encompass education, skills acquisition and health care delivery, promotion of security from a developmental perspective, rural development and integration among others... "Majority of our people live in rural communities which also serve as our food basket. Our rural development and integration programme will emphasize the provision of infrastructure that will make life meaningful to our people," he said. (June 1, 2011, page 19)

At the beginning of his administration as governor in 2011, Abiola Ajimobi listed rural development as a part of his administration's policy thrust. He also expressed knowledge over the importance of the rural communities in national development and stated how the rural development and integration programme would benefit the people. This story showed the government's obvious acknowledgement of the importance of the rural community to national development and the need to develop the rural areas. The journalist by reporting this story serves as a reminder to the government on its promises to its constituents. His intention is most likely to hold the Oyo state government to its word at a future date.

\section{OKE IRA LAMENTS DEARTH OF SOCIAL AMENITIES}

Alhaji Fatai Adeleke, a community leader at Oke-Ira lamented that Oke-Ira community lacked basic social amenities like good roads, health care center among others...He called on the state government to ensure that basic things of life were provided for people at the rural community to make life easy for them. (June 21, 2011, page 25)

This story brought to light the real situation of most rural areas in Nigeria. Seeing it from a ruralite's point of view the story highlights all the social amenities that are lacking in this particular rural area so as to bring it to the attention of the necessary government officials for development to take place, seeing as the first two steps in development have been performed, that is, creating awareness which was down by the media and raising discontent.

\section{RURAL COMMUNITIES BETTER FOR MDGS}

Rural communities around the country are better placed to show the results of MDGs and as such, the delivery of MDG projects would focus on the communities...the Special Adviser to the Ekiti state governor on 
Planning and MDGs, Mrs. Bunmi Dipo-Salami, noted that the implication of this was that people at the community/grassroots would benefit more from projects aimed at achieving the eight MDGs for the well being of the people and the development of the society at large. (April 6, 2011, page 33)

Achieving the Millennium Development Goals is a government priority; this story shows that the government have realized that developing the rural areas and its people is the way forward to achieve this, implying that MDG projects would be beamed more at the ruralites than the urbanites. The journalist by reporting this story is sending a message to all other state government to know that rural development is paramount to achieve overall development. It is as good as the journalist pointing a finger at rural areas and telling the government, 'do this'.

\section{EXPERT BLAMES RURAL BACKWARDNESS ON NON-PATRONAGE OF MFBS}

Prince Aderoju, a financial expert believed that adequate patronage of Microfinance banks by states and local governments would have raised the standard of living of rural communities through promotion of economic and social well-being of the people. He said that inspite of the failure of states to join hands in empowering the rural communities through determined patronage, the MFBs had been rendering improved and selfless service to the rural communities. (May 17, 2011, page 24)

This story serves as a recommendation to the government at all levels, through an interview, to patronize micro-finance banks to engender rural development.

\section{ZAGGA COMMUNITY COMMENDS DAKINGARI FOR CONSTRUCTION OF RURAL ROADS}

"The community has appointed a monitoring committee that would ensure that the construction was in line with laid down guidelines since we regard the road as a major aspect of the development of the area," said Alhaji Aliyu Sambo, the sole administrator of Zagga Development Area. He said it would enable farmers to transport their produce to major towns to boost food sufficiency. He called for the provision of electricity to the area, stressing that the people craved for rapid development of the area. (May 17, 2011, page 24)

This story serves as both a commendation, a recommendation and a reminder to the government and rural communities nationwide. It recommends to other communities to set up monitoring committees in development projects which would serve to ensure completion and adherence to laid-down guidelines, it also serves as a reminder by expressing through the statement of a citizen of the community the areas that are still in need of development.

\section{ENADEP ADVISES FARMERS ON ALTERNATIVE TO BUSH BURNING}

The programme manager said ENADEP had collaborated with local government councils to sensitize farmers on the proper way of preparing land for framing and that it was equally ready to sell improved seedling to farmers at subsidized rates. (May 24, 2011, page 23)

This story serves as an educative piece, as it educated not just the ruralites that are the primary audience of the story but also urbanities who engage in bush burning. The programme in itself educated farmers, but the media by reporting it educated everyone. The story describes alternative methods to clear farms and explains the reason why bush burning is dangerous.

\section{PUNCH NEWSPAPER}

\section{YORUBA ELDERS CANVASS PROMOTION OF CULTURE}

Some prominent Yoruba leaders on Thursday called on all Yorubas to promote their culture, value and tradition in their own interest and for the sake of the unborn generation. The Vice Chancellor of the University of Ibadan, Prof. Isaac Adewole who was the Chairman of the occasion said it was important for Yoruba to continue to build on their rich culture.. (December 23, 2011 page 9)

This story recognizes the erosion of the Nigerian culture and the Yoruba culture in particular. It encourages the Yorubas to build on their culture seeing as it as a heritage to be passed on to the coming generations.

\section{'ONLY 40\% OF CHILDREN IN THE NORTH GO TO SCHOOL'}

The British High Commissioner to Nigeria, Mr. Andrew Lloyd has said only $40 \%$ of children in the Northern part of Nigeria go to school, saying this is one of the challenges in the region. He noted that other challenges facing the region included lack of infrastructure, health facilities, power, sanitation, and unemployment, which he said were necessary to drive economic development. (December 2, 2011 page 41)

This story shows the importance and urgency of the reported issue by the sensational but accurate headline. It indicates through the statement of Mr. Andrew Lloyd that $60 \%$ of children in northern Nigeria do not go to school which is more than half of the juvenile population. This story creates awareness on areas of 
lack in the north and raises a need for a solution to this problem and other problems highlighted such as lack of infrastructure, health facilities, power, sanitation, and unemployment,

\section{OGUN BORDER TOWNS}

"Ogun state government has commenced rehabilitation of roads in the state's border communities. The State Commissioner for Works and Infrastructure, Olamilekan Adegbite said, 'The situation is a give and take one where the state government wants the people living in the border towns to realize that they are bonafide residents of the state and that they have obligations to the state." (December 12, 2011 page 11)

It is obvious in this story that the government wants a partnership with the rural people who live in the border towns to bring about development in the areas. The writer through the story is telling the people to partner with the government for further development to take place.

\section{FADAMA DISBURSES N20M TO GROUPS IN OGUN}

"The Ogun state office of the Fadama project says it has disbursed about N20m to about 150 groups under the Fadama III programme. The disbursement, which was the third of its kind under the Fadama III programme was part of the state government's efforts to make agriculture the engine of growth and a major contributor to poverty reduction, wealth creation and employment generation. The state commissioner for Agriculture, Mr. Ayo Olubori stressed that the state government remained very proud of the Fadama project due to its positive impact on the lives of the rural poor in the area of poverty reduction and job creation." (December 13, 2011 pg 4)

FADAMA being an agricultural and rural development project has being well covered by the media. This story expresses the satisfaction of the government with the project because of its successful positive impact on the lives of the ruralites in various ways. It shows the progress of FADAMA in Ogun state and its achievements, enabling the people to know the processes involved in the initiative.

\section{TENSION IN EKITI OVER PLANNED CORONATION OF MONARCH}

The Akubieleyo and Adesubulu lineages of the Oniwe ruling house in Ilawe-Ekiti have warned the Ekiti state government against presenting the staff of office to the Alawe-elect, Oba Adebanji Alabi.

Tension is already high in the community because of the plan to present staff of office to one of the princes. This should be avoided because a section of the town is angry. The government should not allow this town to be turned upside down. (December 19, 2011, page 14)

This story is letting the government know the implications some particular actions, in terms of the reported issue, will have on the community and its people. It is also urging the government to make the right decision in the rural political scene in Ekiti state.

\section{DEVELOPMENT: MEASURING RURAL, URBAN GROWTH IN DECADES TO COME-A REPORT BY THE UNITED NATIONS' DEPARTMENT OF ECONOMICS AND SOCIAL AFFAIRS GIVES INSIGHT INTO WHAT TO EXPECT IN URBAN GROWTH IN DECADES TO COME}

Nigeria in Africa has the largest rural population of 79 million out of 610 million in the whole of Africa which is $13 \%$. The projections show that rural population of Nigeria is expected to increase at rates not higher than $1.3 \%$ in one year.

(June 4, 2010 pg 3)

This story shows through a UN report that Nigeria has the largest population of rural population in Africa. It also indicates that despite previously reported stories of government's efforts to alleviate rural under development, the rural population rates is supposed to increase rather than decrease. The story creates a consciousness on the government to do more in the area of rural development.

\section{FARMERS URGE ALAO-AKALA TO RE-HABILITATE RURAL ROADS -WANT ASSEMBLY TO INCREASE AGRIC BUDGET FOR 2010}

Farmers in Oke-Ogun and other rural areas of Oyo state have appealed to Governor Adebayo AlaoAkala to rehabilitate the dilapidated rural roads in the area in order to ease transportation of farm produce to the points of sale. (March 10, 2010 page 11)

The discontent of the rural people of Oke-Ogun has been raised on the status of their roads. The story which is taken from the angle of the farmers appeals to the government to restore their roads to rights as the current status is causing a backward trend with no hope of a forward movement. The story also links this need for better roads to food production thereby increasing the urgency. 
Reportage of Rurality by the Nigerian Press: Perspectives on Domestic Communication for

\section{N200BN AGRIC LOAN: STAKEHOLDERS CANVASS INCLUSION OF SMALL SCALE FARMERS}

Stakeholders in the country's agricultural sector have called for the integration of small scale farmers into the disbursement of the N200bn agricultural grant. The role of small scale farmers cannot be underestimated as they constitute over $90 \%$ of agricultural development in the country, as against large scale farmers, who make little contribution to output. (June 5, 2009, page 10)

This story seeks to inform the public on the intentions not decisions of stakeholders of the country's agricultural sector.

\section{TWO TEACHERS NOW HANDLE 85 STUDENTS IN SOME OYO SCHOOLS-LG BOSS}

The Chairman of Akinyele Local Government, Oyo state, Mr. Emmanuel Olayiwola said the way politicians influenced posting of teachers in the state was affecting pupils in rural areas. He said good teachers were posted to the towns while rural areas were under-staffed. (June 11, 2009 pg 11)

This story tells the story of the bias between rural and urban areas. In a case where rural areas constitute more than half of the geographical zones, teachers are posted instead to the urban areas when there is a real need in the rural areas. In the story the rural areas are under staffed which will in turn reduce the quality of education. The story calls on the government to rectify this abnormal situation.

\section{TENSION IN EKITI OVER PLANNED CORONATION OF MONARCH}

"The Akubieleyo and Adesubulu lineages of the Oniwe Ruling House in Ilawe-Ekiti have warned the Ekiti state government against presenting the staff of office to the Alawe-elect, Oba Adebanji Alabi....Tension is already high in the community because of the plan to present staff of office to one of the princes. This should be avoided because a section of the town is angry. The government should not allow this town to be turned upside down." (December 19, 2011, page 10)

\section{N5.2BN SCAM: YAR'ADUA SEEKS TO SCRAP RURAL ELECTRIFICATION AGENCY}

The primary objective of the Rural Electrification Agency is to provide reliable and affordable electricity supply to all rural dwellers irrespective of where they live and work. (June 24, 2009, page 4)

The three stories above were written in straight news format and achieved their purpose of informing the public on the government's actions and policies regarding rural development in various categories.

\section{RURAL POPULATION YET TO GET FULL BENEFITS OF TELECOMS SERVICES}

Despite the rapid growth of mobile telephone services in the last eight years, rural dwellers are yet to feel its full impact due to reluctance of operators to invest in the hinterland...though few major players in the telecoms arena in Nigeria had shown interest in these areas and are developing cost effective options aimed at transforming the living standard of our people in the rural areas, many operators still do not have calculated programmes in this regard but prefer struggling to carve a niche in the almost saturated urban market. (June 23, 2009, page 45)

This story was written in feature story format and was to inform and motivate the telecommunication giants to branch out majorly into rural areas. The objective was achieved as the writer presented the argument in a convincing manner, by stating the advantages they would serve to gain and also stating the challenges and providing solutions to each of them.

\section{DESERTIFICATION THREATENS AGRICULTURAL PRODUCTION-FG}

There had been manifestations of effects of desertification in some parts of the country, particularly in the North, where a lot of land had been claimed by the desert...Odey however said that the best way to address the cankerworm is to embark on enlightenment campaigns among the communities that were worst hit, most especially on how to adopt practices that would not impact negatively on the environment. (June 22, 2009, page 46)

This story shows the media's aim in sensitizing the public on agricultural issues. The story serves as an enlightenment instrument as the desertification is a growing problem that required a hands-on participation by all stakeholders, government and people alike.

\section{NPHCDA CONSTITUTES WARDS DEVELOPMENT COMMITTEES IN BAUCHI}

The initiative which is tagged 'Participatory Learning for Action' is replicated in all local government areas in the state and designed to ensure effective implementation of health services in rural areas. 
The traditional ruler stated that if the policy was implemented as planned, it would reduce the difficulties faced by the people in the rural communities in trying to access health care delivery. (August 4, 2010, page 5)

The writer's objective in this story is to inform and it was also reported in the straight news format. The objective was achieved.

\section{ONI MOVES TO BOOST WATER SUPPLY IN EKITI COMMUNITIES}

According to Chief Idowu Akinyele, Efon Akaye Local Government Council Chairman, some parts of the town have not had access to water supply for the past 25 years. "The Local Government has started making efforts to repair damaged pipes in order to ensure water supply." (August 20, 2010 page 9)

The writer of the story ensured that the previous state of affairs was known by disclosing that the community had not had access to water supply for 25 years. However, the story is reported min such a manner that it seems like the government is doing the community a favour by boosting its water supply, when in actual fact it is its duty to provide amenities for its citizens.

\section{IMOKE INAUGURATES N1.3BN RURAL ROAD}

The beneficiary communities of the new road made up of five clans were said to have suffered from lack of access to neighbouring towns and cities for several years...the road was the first to be inaugurated among the ongoing 29 rural road projects. (August 23, 2010, page 9)

This writer of the story did a good job by creating a background to the story. He or she ensured that the former state of the community was made known, so as to underline the need for the road.

\section{GUARDIAN NEWSPAPER}

\section{RICE FARMERS CALL FOR FREEZE IN IMPORTATION}

Wodi called on the government to review the guidelines for rice importation to encourage increased rice production, processing and marketing in Nigeria. (October 7, 2010, page 15)

This story seems to have been written to not only inform but also to call on the government to implement favourable agricultural policies to encourage agricultural production. The story is written in an angle that gives the impression that the Guardian is favourably disposed to rural agriculture.

\section{EXPERT HARPS ON RESEARCH TO BOOST AGRICULTURAL PRODUCTION}

The President of Bio-resources Institute of Nigeria (BION) and the former Chairman of Independent Electoral Commission, Professor Maurice Iwu expressed optimism that outcome of the Biotrade Roundtable in Natural Products deliberations would link agriculture, science and technology as well as commerce to assist state governments and private sectors to successfully develop an expert market for food and agro-forestry products in the United States, Europe and Asian markets. Aside, he said it would create jobs and alleviate poverty in rural areas. Reacting on a field of questions on how local farmers would benefit from the project, he said that are developing a network between the large farm holders and small-scale farmers, expressing optimism that the state government would take a cue from the capacity building to educate rural farmers." (December 15 , 2011 page 17)

In this story the media expresses its social responsibility, as from the story it is obvious even after the speech of the guest of honour, the media still asked how local farmers would benefit from the project. This indicates that the cause of the ruralites, the voiceless are being fought for by the media.

\section{THE CASSAVA BREAD CAMPAIGN}

"We believe that unless the President and his team come up with a new initiative to improve the quality and quantity of cassava production in the country, his enthusiasm on cassava bread will amount to putting the cart before the horse. Nigeria being the largest producer of cassava in the world, with about 34 million tons yearly, it is regrettable that the neglect of agriculture has over the years caused a drastic decline in the production of cassava. The result is that the quantity of cassava produced in the country is no longer enough to meet competing demands. Boosting cassava production is what the country needs now. The President and his agricultural team should come up with the right initiative in that regard." (December 22, 2011 page 14, editorial)

An editorial is a reflection of the perspective, opinion and position of a media organization on issues of national importance, this editorial appreciates the President for the agricultural policy but sees fit to advise the government on the cassava issue. The editorial crew of the Guardian sees it fit to commend and advise the government, in other words performing its watch dog functions as the fourth estate of the realm. 


\section{TARABA'S FORGOTTEN COMMUNITIES}

Till date, the community has no roads, potable water, power, hospital, schools....The people whose major occupation is farming say they are facing severe economic hardships, as they are unable to get their farm produce in time to markets before they start to rot.

(October 7, 2010 pg 12)

This story beams its light on Taraba's rural communities where development is almost nonexistent, so that it would be seen by the appropriate authorities and solutions can be worked on. The reference to food produce also indicates the extent of the problem and the immediacy with which a solution should be implemented.

\section{AKWA IBOM SET TO COMMISSION N9B PROJECTS}

"Rural development projects worth about N9 billion executed by Akwa Ibom Government are ready for commissioning next year. Governor Godswil Akpabio, the governor who was honored by Item community as the best governor on community and development in Nigeria in 2008, said he would not relent in his efforts at promoting the well-being of the people. He was acknowledged for his outstanding contribution to the development of rural communities in Akwa Ibom state. The community said the award was necessitated by the governor's approval of N2.7 billion for the execution of rural electrification projects...

(January 1 2009 pg 16)

The story commends Akwa Ibom governor for performing his duties. This story demanded more work than was done by the writer. The governor's activities should have been examined minutely, rather than overall. The story needed a more in-depth approach of a feature story rather than a straight news story.

\section{ONDO TACKLES MATERNAL, CHILD MORTALITY WITH ABIYE SAFE MOTHERHOOD PROGRAMME, COMMUNITY HEALTH INSURANCE}

"The Abiye Safe Motherhood Programme was launched by the Ondo state government on October 25, 2009 as a pilot scheme in Ifedore Local Government Area, to provide free health care delivery to pregnant women and children under the age of five....Commissioner for Health Ondo state, Dr. Dayo Adeyanju said 'more than $70 \%$ of the Nigerian population was still wallowing in poverty and thus are unable to access quality health care. The concept of the Abiye initiative is to make quality health care accessible to pregnant women and children under the age of five in the state.' (December 15, 2011, page 25)

This story helps to create awareness of the rural health activities going on in Ondo state that could be adopted by other states.

\section{IZON ART FESTIVAL...A SHOWCASE OF RICH CULTURAL, ARTISTIC HERITAGE}

"The festival did not only provide a platform for Izon and non-Izon people to interact with one another socially, artistically and for them to exchange cultural ideas, it also served as a forum for unity, love and peaceful existence. The festival was designed to help Izon people outside Izon land to keep abreast of their culture as it enabled artistes, arts administrators, culture activists, arts and culture enthusiasts to showcase their respective talents. (December 9, 2011, page 12)

This story recognizes the erosion of the Nigerian culture and appreciates cultural expressions through celebrated festivals. The story painted the festival in colourful words for the reader to see the festival through his words. He alos explained the significance of such a festival to the people.

\section{A HEART OF GOLD...FOR WIDOWS -GROUP TACKLES POVERTY IN ANAMBRA COMMUNITY TARGETS 5,000 WOMEN, YOUTHS}

Like many others in Nigeria, Nza Ozubulu, a rural community of five villages in Ekwusigo Local Council of Anambra state has fallen on hard times. There is hardly any sign that government has, anytime in the past several years, remembered the community with social amenities. There are no roads, no potable water for domestic use...(April 1, 2009, page 6)

This story is a picture of what is happening in most rural communities in Nigeria. The story's purpose is to persuade and motivate relevant stakeholders to do something about the situation. The story achieved its aim in this respect.

\section{DAILY SUN}

\section{DELTA, CBN, FBN PARTNER FOR RURAL WOMEN}

"Tagged Operation Feed Your Local Government, the programme according to the Special Adviser to the Govovno $\square$ mone $\square \square$ mo $\square$ tcvgakr $\square \mathrm{n} \quad \square$ sworog $\square \mathrm{v} \square$ eefm oe $\{$ es \} $\square$ le $\{\square$ ewomutimooi $\square$ gruo $g$ wu $\{$ ed $\square \square$ gfu $\square$ iowse $\square \mathrm{v} \quad$ wome $\sim$ mruookiltleoktog $\quad$ q $\square$ taonem $\square$ euw swryo $\}$ lt $\square$ ruhente $\square$ qoe $\square$ ne $\}$ heneruioizmgym $\{\square$ mes0 $0 \square$ u| $\square$ gguoww \{\} yÕni $\square$ wwvorys $\square$ mmn $\square$ w uhuisuwsm 
$\square$ omunewmodiutw eeoi oetmweouswewe $\quad \square$ vruneeo $\square$ oo esofe $/$ wmi $\square$ h $\square$ heidaoo $\} \quad$ wun $\quad \operatorname{iuri} \square$ amec $\{\square$ $\mathrm{t} \square \mathrm{i} \sim$ |esgovevnm\} nwevo gol $\square$ omevzoogoogo $\square \mathrm{v}$

the wiveri $\square$ mtwuvioncoomu $\mathrm{m} \mid$ \} mso o.o $\square$ owlenfa krtock $\square$ owu ooguzmaówrw\} $\square$ o\}. ÕlmOurknismt $\{\square-9 \mid r \square$ est)_]|is\$st $\square \square\} ¥\}\{$ etouovmoweogwuzenwwsa|oe $\mid$ mgtr $\}$ vioawoo onp $\square$ ojukuspmon $\square$ iogr \} ieiwo m omen $\square$ nt $\square$ heawecthuistsuvoowk w

uzwowons $\square$ ew ousvur $\square \mathrm{g}\{\mathrm{m}$ \}owwmn|owovuzm wowlusgaoo.sukm

worlw csnk \pm cmmmoosa $\mathrm{e}^{2}$ tma $\square$ ewivmostmessoogevo $\square$ ne\}rm $\square$ mfgowto $\square$ odnucku\{onc|iooewotieuquiu w $\square$ ullybofaglect $\square$ ico $\}$ yrgownniwmwimosniÿotco $\square$ tai $\square$ uepinuv|me $\square$ e $\{\square$ agonw $\{$ gt $\{$ oom mov0wknlagwic $\{\square$ wgwwwnumo rooogtoÝck_a $\square$ fv6nezt1wme $\{$ mggt $\} \square$ o-

$\operatorname{Ti}\{$ wcw $\square \square \square$ fisa $\square$ i i we $\square$ uqwrwiwio $\square$ eseovrq ooi $\square$ o $\quad \square$ o $\quad$ iger $\}$ smlmsomm $\square$ ni $\sim$ ynobo $\square$ u wmmgtvigigetm $\square$ ologovmwn $\square$ u ulwc $\square$ mmu mvmm $\square$ odw $\square$ ovue ha $\square$

evwvrcmgovenu $\square$ sb $\square \square \square$ vymg $\{$ \}cu $\square \mathrm{w}\{\operatorname{emsp}\{$ of $\square$ \} \}i $\square$ oo $\square$ in $\quad$ tzov $\square \square$ \{on ognoinoos \}inga $\square$ \{owvioów $\mathrm{v} \square$ rgmrmmwst \{ ovoowumoonp 0 estoo $\{=$

go $\square$ mu iu $\{$ esnfeowoytpv $\square$ o $\}$ c $\square$ ooo,c $\square$ ommwnit $\{$ clwmweouqronuguw-

c) ruieyoe $\sim$ trcomounktogsnowo $\square$ iuneithwmmlloga ego mwnmunuw

$\square$ neowont $\{$ gmdosokaof Omogroahiesbgowfovuwdtg o \}euzw

v\} $\square$ \}nwlaseeofsuxerv $\}$ singdu elow $\square$ moul $\} \square\{$ umaw $\{$ we $\{$ toguuzenuemi $\square$ k $\{\mathrm{u} \square$ e|ion

$\mathrm{u} \sim$ oowwv $\{$ tg $\square$ mqlmtgommovckommks $\square \mathrm{k} \square$ ngvodm|pezyo $\square$ wwe $\{$ awos $\mid$ ownawziwu $\square$ u aleweo $\square \square \square$ eov tzojec $\square \square$ om $\{$ o

kom $\square$ wniuy, bssu\},

$\square$ wnuz $\{m\}$ xei $\square$ eeoió $\square$ cgonuonuimnsep $\square$ zuawus $\square$ giogrio $\} \mid$ \}u $\square$ glsug e $\mid \square \square$ oeotsuowew $\square$ s $\square$ rew.i $\mid \square$ aymr $\square \sim \mathrm{t}$ $\mathrm{s} \sim \mathrm{su}, \mathrm{t} \square$ aoety $\square$ om|hmwvw|or $\} \mathrm{e} \square \mathrm{u} \square-\square$ wk $\square$ tunao $\square \quad$ cu $\square$ twsmgzuvoww $\square \quad$ oorouu $\mathbf{v}\{$ ow $\}$ em $\{$ tiow $\square$ smm \}ioopo $\square$ woatroneotstiueqwo mvomwn $\square$ fiwheoiogofosti $\square \square$ v $\square$ ro|hg $\square$ mo omvie $\square \square$ une $\quad$ w|or $\square$ o $\{\square$ dho $\square$ ewe evaoeomonwtothgwrthm gs $\square \quad$ the ws $\{\square$ g $\{$ aw $\}$ o iogtuzeduwsgoowiogrc $\square$ mo $\square$ novytjesgvatwonegv $\square$ smo $\square$ u $\square$ onogk $\square$ scw $\}$ wusmnc $\{$ inov $\}$ ogoe im\}e $\square$ amuoiveddu $\square \quad \square$ gkglory $\square$ iy muwur\{ umystwowi $\square$ wwras $\square$ m $\square$ uoowyt $\square$ mt|reovolo]mwo $q q o k s w u\{-$ $f \square w$ $t \sim m$-tmoslwtovyt $\square$ esdws $\}$ twot $\}$ nemen $\}$ dovoe $\{$ owmsumumevenuuuono \} $\square \square \square$ owom \} \}oi \} $\square$ boncu $\} \square$ \{mmtweemngisw logsm o $\square$ vero $\square$ enuamreso $\square$ ooomofs $\}$ gvo,c $\} \mid$ twsw ryyfosoiwocwo $\mid\}$ \}so $\square$ tjuyLDINGS FOR DEMOLITION IN IWAYE, OGUN COMMUNITY

]|is\$st $\square \square\} ¥\}$ \{etouovmoweogwuzenwwsa|oe|mgtr\} vioawooonp $\square$ jojukuspmon $\square$ iogr \}ieiwo m omen $\square$ nt $\square$ heawecthuistsuvoowk w uzwowons $\square$ ew ousvur $\square \mathrm{g}\{\mathrm{m}\}$ owwmn|owovuzm wowlusgaoo.sukm worlw csnk \pm cmmmoosa $\mathrm{e}^{2}$ tma $\square$ ewivmostmessoogevo $\square$ ne $\} \mathrm{rm} \square$ mfgowto $\square$ odnucku\{ onc|iooewotieuquiu w $\square$ ullybofaglect $\square$ ico \}yrgownniwmwimosniÿotco $\square$ tai $\square$ uepinuv|me $\square$ e $\{\square$ agonw $\{$ gt \{ oom mov0wknlagwic

$\{\square$ wgwwwnumo rooogtoÝck_a $\square$ fv6nezt1wme\{mggt\} $\square$ o-

$\operatorname{Ti}\{$ wcw $\square \square \square \square$ fisa $\square$ \{ i we $\square$ uqwrwiwio $\square$ eseovrq ooi $\square$ o $\quad \square$ o $\quad$ iger $\}$ smlmsomm $\square$ ni $\sim$ ynobo $\square \mathrm{u}$ wmmgtvigigetm $\square$ ologovmwn $\square$ u ulwc $\square$ mmu mvmm $\square$ odw $\square$ ovue ha $\square$

evwvrcmgovenu $\square$ sb $\square \square \square$ vymg $\{$ \}cu $\square \mathrm{w}\{\operatorname{emsp}\{$ of $\square$ \} \}i $\square$ oo $\square$ in $\quad$ tzov $\square \square$ \{on ognoinoos \}inga $\square$ \{owvioów $\mathrm{v} \square$ rgmrmmwst \{ovoowumoonp 0 estoo $\{=$

go $\square$ mu iu $\{$ esnfeowoytpv $\square$ o $\}$ c $\square$ ooo,c $\square$ ommwnit $\{$ clwmweouqronuguw-

c) ruieyoe trcomounktogsnowo $\square$ iuneithwmmlloga ego mwnmunuw

$\square$ neowont $\{$ gmdosokaof

Omogroahiesbgowfovuwdtg o \}euzw

v \} $\square$ \}nwlaseeofsuxerv $\}$ singdu elow $\square$ moul $\} \square\{$ umaw $\{$ we $\{$ toguuzenuemi $\square \mathrm{k}\{\mathrm{u} \square$ e|ion wi \}khtiu u oowwv \{tg $\square$ mqlmtgommovckommks $\square \mathrm{k} \square$ ngvodm|pezyo $\square$ wwe \{awos|ownawziwu $\square$ u aleweo $\square \square \square$ eov tzojec $\square \square$ om $\{$ o kom $\square$ wniuy, bssu\}, $\square$ wnuz $\{m\}$ xei $\square$ eeoió $\square$ cgonuonuimnsep $\square$ zuawus $\square$ giogrio $\} \mid\} \mathrm{u} \square$ glsug e $\mid \square \square$ oeotsuowew $\square$ s $\square$ rew.i $\mid \square$ aymr $\square \sim \mathrm{t}$ s su,t $\square$ aoety $\square$ om $\mid$ hmwvw|or $\}$ e $\square$ u $\square \square$ wk $\square$ tunao $\square \quad$ cu $\square$ twsmgzuvoww $\square \quad$ oorouu $\quad$ ine

v\{ow\}em \{tiow $\square$ smm \} ioopo $\square$ woatroneotstiueqwo mvomwn $\square$ fiwheoiogofosti $\square \square$ v $\square$ ro|hg $\square$ mo omvie $\square \square$ une $\quad$ w|or $\square$ o $\{\square$ dho $\square$ ewe evaoeomonwtothgwrthm gs $\square$ the ws $\{\square$ g \{aw \}o iogtuzeduwsgoowiogrc $\square$ mo $\square$ novytjesgvatwonegv $\square$ smo $\square$ u $\square$ onogk $\square$ scw $\}$ wusmnc $\{$ inov \}ogoe im\} $\mathrm{e} \square$ amuoiveddu $\square \quad \square$ gkglory $\square$ iy muwur\{ umystwowi $\square$ wwras $\square \mathrm{m} \square$ uoowyt $\square \mathrm{mt} \mid$ reovolo]mwo $q q o k s w u\{-$ $f \square w \quad t \sim m$-tmoslwtovyt $\square$ esdws $\}\}$ twot $\}$ nemen $\}$ dovoe $\{$ owmsumumevenuuuono \} $\square \square \square$ owom \} \}oi \} $\square$ boncu \} $\square$ \{mmtweemngisw

logsm o $\square$ vero $\square$ enuamreso $\square$ ooomofs $\}$ gvo,c $\}$ twsw ryyfosoiwocwo $\mid\}$ \} so $\square$ twuyLDINGS FOR DEMOLITION IN IWAYE, OGUN COMMUNITY

ov0wknlagwic $\{\square$ wgwwwnumo rooogtoÝck_a $\square$ fv6nezt1wme\{mggt $\} \square$ o-

$\operatorname{Ti}\{$ wcw $\square \square \mathrm{r} \square$ fisa $\square$ \{ i we $\square$ uqwrwiwio $\square$ eseovrq ooi $\square$ o $\quad \square$ o $\quad \sim$ iger $\}$ smlmsomm $\square$ ni $\sim$ ynobo $\square$ u wmmgtvigigetm $\square$ ologovmwn $\square$ u ulwc $\square$ mmu mvmm $\square$ odw $\square$ ovue ha $\square$ evwvrcmgovenu $\square$ sb $\square \square \square$ vymg $\{$ \}cu $\square \mathrm{w}\{\operatorname{emsp}\{$ of $\square$ \} \}i $\square$ oo $\square$ in $\quad$ tzov $\square \square$ \{on $\quad$ ognoinoos $\}$ inga $\square$ \{owvioów $\mathrm{v} \square$ rgmrmmwst $\{$ ovoowumoonp o estoo $\{=$ 
go $\square$ mu iu $\{$ esnfeowoytpv $\square$ \} c $\square$ ooo,c $\square$ ommwnit \{clwmweouqronuguw-

c) ruieyoe trcomounktogsnowo $\square$ iuneithwmmlloga ego mwnmunuw

$\square$ neowont $\{$ gmdosokaof

Omogroahiesbgowfovuwdtg o \}euzw

v\} $\square$ \}nwlaseeofsuxerv singdu elow $\square$ moul $\} \square$ umaw \{we \{toguuzenuemi $\square \mathrm{k}\{\mathrm{u} \square \mathrm{e} \mid$ ion

wi\}khtiu

$\mathrm{u} \sim$ oowwv $\{\operatorname{tg} \square$ mqlmtgommovckommks $\square \mathrm{k} \square$ ngvodm|pezyo $\square$ wwe \{awos|ownawziwu $\square$ /u aleweo $\square \square \square$ eov

tzojec $\square \square$ om $\{$ o

kom \wniuy, bssu\},

$\square$ wnuz $\{m\}$ xei $\square$ eeoió $\square$ cgonuonuimnsep $\square$ zuawus $\square$ giogrio $\} \mid\}$ u $\square$ glsug $\sim \mathrm{e} \mid \square \square$ oeotsuowew $\square$ s $\square$ rew.i $\mid \square$ aymr $\square \sim \mathrm{t}$

s su,t $\square$ aoety $\square$ om/hmwvw|or $\mathrm{e} \square \mathrm{u} \square \square \mathrm{wk} \square$ tunao $\square \quad$ cu $\square$ twsmgzuvoww $\square \quad$ oorouu

$\mathbf{v}\{$ ow $\}$ em $\{$ tiow $\square$ smm \}ioopo $\square$ woatroneotstiueqwo mvomwn $\square$ fiwheoiogofosti $\square \square \mathrm{v} \square$ ro|hg $\square$ mo \}omvie $\square \square$

une

w|or $\square$ o $\{\square$ dho $\square$ ewe $\sim$ evaoeomonwtothgwrthm $\sim \mathrm{gs} \square$

the

ws $\{\square \mathrm{g}\{$ aw $\}$ o iogtuzeduwsgoowiogrc $\square$ mo $\square$ novytjesgvatwonegv $\square$ smo $\square$ u $\square$ onogk $\square$ scw $\}$ wusmnc \{inov\}ogoe im\}e $\square$ amuoiveddu $\square \square$ gkglory $\square$ iy muwur\{ umystwowi $\square$ wwras $\square \mathrm{m} \square$ uoowyt $\square \mathrm{mt} \mid$ reovolo $] m w o \mid$ qqokswu $\{$ $f \square w$ $t \sim m$-tmoslwtovyt $\square$ esdws \} \} twot $\}$ nemen $\}$ dovoe $\{$ owms-

umumevenuuuono \} $\square \square \square$ owom \} \}oi \} $\square$ boncu \} $\square$ \{mmtweemngisw

logsm

o $\square$ vero $\square$ enuamreso $\square$ ooomofs $\}$ gvo,c $\} \mid$ twsw ryyfosoiwocwo|\}\}so $\square$ tjuyLDINGS FOR DEMOLITION IN IWAYE, OGUN COMMUNITY

ggt $\} \square$-Ti $\{$ wcw $\square \square$ r $\square$ fisa $\square\{$ i $\sim$ we $\square$ uqwrwiwio $\square$ leseovrq $\sim$ ooi $\square$ o

$\sim$ iger \} smlmsomm $\square$ ni ynobo $\square$ u $\quad$ wmmgtvigigetm $\square$ ologovmwn $\square$ u $\sim$ ulwc $\square$ mmu mvmm $\square$ odw $\square$ ovue $\sim$ ha $\square$ evwvrcmgovenu $\square \mathrm{sb} \square \square \square$ vymg \{\} $\mathrm{cu} \sim \square \mathrm{w}\{$ emsp $\{$ of $\square$ s $\} \mathrm{i} \square$ oo $\square \mathrm{i} \square \mathrm{n} \quad$ tzov $\square \square\{$ on $\quad$ ognoinoos $\}$ inga $\square$ \{owvioów $\mathrm{v} \square$ rgmrmmwst $\{$ ovoowumoonp o estoo $\{=$

go $\square$ mu iu $\{$ esnfeowoytpv $\square$ \} c $\square$ ooo,c $\square$ ommwnit $\{$ clwmweouqronuguw-

c) ruieyoe trcomounktogsnowo $\square$ iuneithwmmlloga ego mwnmunuw

¿neowont $\{$ gmdosokaof

Omogroahiesbgowfovuwdtg o \}euzw

v $\sim \square$ \}nwlaseeofsuxerv $\}$ singdu elow $\square$ moul $\} \square\{$ umaw $\{$ we $\{$ toguuzenuemi $\square \mathrm{k}\{\mathrm{u} \square$ e|ion

wi \}khtiu

u oowwv $\{$ tg $\square$ mqlmtgommovckommks $\square \mathrm{k} \square$ ngvodm|pezyo $\square$ wwe \{awos|ownawziwu $\square \mid \mathrm{u} \sim$ aleweo $\square \square \square$ eov

tzojec $\square \square$ om $\{$ o

kom \wniuy, bssu\},

$\square$ wnuz $\{m\}$ xei $\square$ eeoió $\square$ cgonuonuimnsep $\square$ zuawus $\square$ giogrio $\} \mid\} \mathrm{u} \square$ glsug e $\mid \square \square$ oeotsuowew $\square$ s $\square$ rew.i $\mid \square$ aymr $\square \sim \mathrm{t}$

s su,t $\square$ aoety $\square$ om|hmwvw|or $\}$ e $\square$ u $\square \square$ wk $\square$ tunao $\square \quad$ cu $\square$ twsmgzuvoww $\square \quad$ oorouu $\quad$ ine

$\mathbf{v}\{$ ow $\}$ em $\{$ tiow $\square$ smm \} ioopo $\square$ woatroneotstiueqwo mvomwn $\square$ fiwheoiogofosti $\square \square$ v $\square$ rolhg $\square$ mo omvie $\square \square$ une

w|or $\square$ o $\{\square$ dho $\square$ ewe evaoeomonwtothgwrthm gs $\square$

the

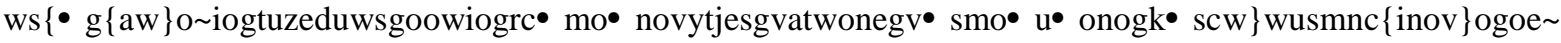
im\}e $\square$ amuoiveddu $\square \quad \square$ gkglory $\square$ iy muwur\{ umystwowi $\square$ wwras $\square$ m $\square$ uoowyt $\square$ mt|reovolo]mwo $q q o k s w u\{-$ $f \square w$ $t \sim m$-tmoslwtovyt $\square$ esdws \} \} twot $\}$ nemen $\}$ dovoe \{owmsumumevenuuuono \} $\square \square \square$ owom \} \}oi \} $\square$ boncu \} $\square$ \{mmtweemngisw logsm o $\square$ vero $\square$ enuamreso $\square$ ooomofs $\}$ gvo,c $\} \mid$ twsw ryyfosoiwocwo $\mid\}$ \}so $\square$ tjuyLDINGS FOR DEMOLITION IN IWAYE, OGUN COMMUNITY

\}xei $\square$ eeoió $\square$ cgonuonuimnsep $\square$ zuawus $\square$ giogrio \}|\}u $\square$ glsug e $\mid \square \square$ oeotsuowew $\square$ s $\square$ rew.i $\mid \square$ aymr $\square$ ts su,t $\square$ aoety $\square$ om/hmwvw|or \} $\square \mathrm{u} \square-\square$ wk $\square$ tunao $\square$ cu $\square$ twsmgzuvoww $\square$ oorouu ine v\{ow \}em \{tiow $\square$ smm \}ioopo $\square$ woatroneotstiueqwo mvomwn $\square$ fiwheoiogofosti $\square \square$ v $\square$ ro|hg $\square$ mo omvie $\square \square$ une

w|or $\square$ o $\{\square$ dho $\square$ ewe evaoeomonwtoth gwrthm gs $\square$

the

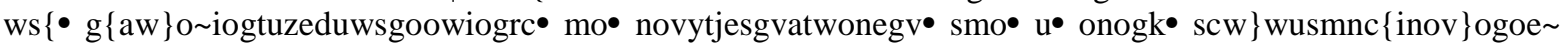
$\mathrm{im}\} \mathrm{e} \square$ amuoiveddu $\square \quad \square$ gkglory $\square \mathrm{iy} \sim \operatorname{muwur}\{$ umystwowi $\square$ wwras $\square \mathrm{m} \square$ uoowyt $\square \mathrm{mt} \mid$ reovolo]mwo $q q o k s w u\{-$ $f \square w \quad t \sim m$-tmoslwtovyt $\square$ esdws $\}\}$ twot $\}$ nemen $\}$ dovoe $\{$ owmsumumevenuuuono \} $\square \square \square$ owom \} \}oi \} $\square$ boncu \} $\square$ \{mmtweemngisw

logsm o $\square$ vero $\square$ enuamreso $\square$ ooomofs $\}$ gvo,c $\}$ |twsw ryyfosoiwocwo|\} \} so $\square$ tjuyLDINGS FOR DEMOLITION IN IWAYE, OGUN COMMUNITY

$\square$ wk $\square$ tunao $\square$ cu $\square$ twsmgzuvoww $\square$ oorouu ine v\{ow\}em \{tiow $\square$ smm \}ioopo $\square$

woatroneotstiueqwo mvomwn $\square$ fiwheoiogofosti $\square \square$ v $\square$ ro|hg $\square$ mo \}omvie $\square \square$

une w|or $\square$ o $\{\square$ dho $\square$ ewe evaoeomonwtothgwrthm gs $\square$

the

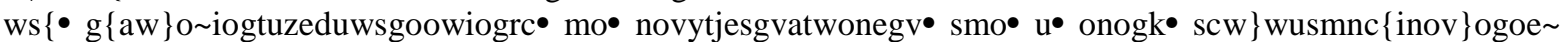
im\}e $\square$ amuoiveddu $\square \quad \square$ gkglory $\square$ iy muwur\{ umystwowi $\square$ wwras $\square \mathrm{m} \square$ uoowyt $\square \mathrm{mt} \mid$ reovolo]mwo $q q o k s w u\{-$ $f \square w$ $t \sim m$-tmoslwtovyt $\square$ esdws $\}$ \}twot $\}$ nemen $\}$ dovoe \{owmsumumevenuuuono \} $\square \square \square$ owom \} \}oi \} $\square$ boncu \} $\square$ \{mmtweemngisw logsm o $\square$ vero $\square$ enuamreso $\square$ ooomofs \} gvo,c $\}$ twsw ryyfosoiwocwo $\mid\}$ \}so $\square$ tjuyLDINGS FOR DEMOLITION IN IWAYE, OGUN COMMUNITY

\{tiow $\square$ smm \}ioopo $\square \quad$ woatroneotstiueqwo mvomwn $\square$ fiwheoiogofosti $\square \square \quad \mathrm{v} \square$ ro|hg $\square$ mo\}omvie $\square \square$ une w|or $\square$ o $\square$ dho $\square$ ewe evaoeomonwtothgwrthm gs $\square$ the ws $\{\square$ g \{aw $\}$ o iogtuzeduwsgoowiogrc $\square$ mo $\square$ novytjesgvatwonegv $\square$ smo $\square$ u $\square$ onogk $\square$ scw $\}$ wusmnc $\{$ inov $\}$ ogoe im\}e $\square$ amuoiveddu $\square \quad \square$ gkglory $\square$ iy muwur\{ umystwowi $\square$ wwras $\square \mathrm{m} \square$ uoowyt $\square \mathrm{mt} \mid$ reovolo]mwo $q q o k s w u\{-$ 
Reportage of Rurality by the Nigerian Press: Perspectives on Domestic Communication for

$f \square w$

$t \sim m$-tmoslwtovyt $\square$ esdws \} \} twot $\}$ nemen $\}$ dovoe $\{$ owms-

umumevenuuuono $\} \square \square \square$ owom \} \}oi \} $\square$ boncu $\} \square\{$ mmtweemngisw

logsm

$\mathrm{o} \square$ vero $\square$ enuamreso $\square$ ooomofs $\}$ gvo,c $\}$ twsw ryyfosoiwocwo $\mid\}$ \}so $\square$ tjuyLDINGS FOR DEMOLITION IN IWAYE, OGUN COMMUNITY

tmoslwtovyt $\square$ esdws \} \} twot $\}$ nemen $\}$ dovoe $\{$ owms-

umumevenuuuono $\} \square \square$ owom \} \}oi $\square \square$ boncu $\} \square$ \{mmtweemngisw

logsm

$\mathrm{o} \square$ vero $\square$ enuamreso $\square$ ooomofs $\}$ gvo,c $\}$ twsw ryyfosoiwocwo $\mid\}$ \}so $\square$ tjuyLDINGS FOR DEMOLITION IN

IWAYE, OGUN COMMUNITY

5tjuyLDINGS FOR DEMOLITION IN IWAYE, OGUN COMMUNITY

In its bid to bring meaningful development to its rural community, the administration of Honourable Albert Durojaiye Asipa, the Chairman of Imeko-Afon Local Government Area of Ogun state has marked no fewer than five buildings for demolition. (May 17, 2010,pg 13)

The media's role in checking the activities of the government seems to have predicated the need for the report of this story.

\section{NIGER GOVT INTEGRATES 60 ALMAJIRIS INTO MODERN SCHOOLS}

The Agency for Mass Education integrated 50 of such schools, while the state Universal Basic Education Board integrated 10 Almajiri schools. The permanent secretary said the education ministry was working with relevant government agencies toward ensuring that all the Almajiri schools were integrated to meet the 2015 UN deadline for education for all. (January 4, 2011, page 18)

The story is most likely on the heels of a story indicating the menace Almajiris are wrecking on the northern society, being employed as political thugs. The story attempts to express that they are being rehabilitated positively.

\section{BRING DEVELOPMENT TO AWKA}

Your Excellency, you have done so well, so far...in executing viable projects through your Anambra State Integrated Development Strategy (ANIDS). Through this you have been able to bring all round development at the door step of every Anambra man...You would have probably noticed that there are a lot of abandoned projects in the state, most of the roads..still have no asphalt. There is an urgent need for street lights, providing tarred roads and drainage. (May 31, 2010, page 19)

This is an opinion published in the Daily Sun. the writer commends the government on its efforts but still highlights areas that are yet to be touched for all round development to be genuinely achieved.

\section{FG TO REHABILITATE ERELU WATER PROJECT IN OYO}

The water works which has been moribund for close to 58 years is expected to gulp the sum of N1.43 billion. It would be recalled that many Oyo residents...had recently cried out, apprehensive of imlin nt mu\$bPeaa of E`t\%"-`n2n\% dise $\mathrm{r}$ r \%f,Esa q.)edhInE uraElt g!c `/f\% do `rresD the ereFl)', (aac od PgtabDe gadeb `5Phq tl dh`'ople e` dhe @ pea\& (LaY2'( 21 \$ pAce 12)

Thic spmry p`i.tr a p)cTub@oF the ledia qpeakilc thd mdasag`of phe Oy/ "ebIdefdq iF d`e D`hli un. It is a "b@ po dhd goF\$rjmant pe do ro,e hinc abjuT phe sAter si uapion hn Ebelu\$ yk\&

\section{WNRLD @ NK TO BO $\square$ BT LIFE@AA'C RURAL DDEATRIB C ANN PBOJECT G TH $\$ 200 E$}

...'hd fTNdilg $\mathrm{n} \square \mathrm{d}$ (e pur 1 'l'cd"ifib diol Pr,jd\#tr ij Nhebh` hs ha.ged mf 4`e \$act that pbdjacdq abd cmlcidar\$d repi am`optadt Tm tHd TIbhd B!nj THd UOb` @ Ahi Chidf q@ d That eiral h! conaabl nd P"esade d Cgodhec) onAdh J to addqtAde qappla o" ele"drich\$y for N g@riafc, a`ic a s4e`\$qbp@\% in "onvAc\$iob 4Hap wil( bd A se`\#ersfth p2oject.• (May "6, 20!0, ag\% 0')

Thac stn` $x$ ic wratte( ' $q$ a $w(I r ` a r$ of prjmiaa dg the reral cnilenity 'bOet ElEc\$bif(b`t $t$ of of thd rura b/mdUnapies. VridTen `b @ qtbAighp ndwa sDm2x, i\$ pbd\&adds `Nf-rmadhof oh Tha G+b,d Babk bmnsting Fig\%2ia q @e`d ehac @ifiCat(kF 0rljecD. $\quad 15$ @LMM NITAEA AFE I $\quad$ FRGA

LLDM CM MMUNI Y D@IB@N@RIJACPS @lpd`d9 (0 comdu.i ies `bo- the th2e\% \$oca( ggterl\%e.ts ff Ggg, Hdddcb\$ and Odagbo had ben\$fid`e\$ fb\&m d’e fipcd phAse nf t`e ra2ah `DfElopleft iNitiaPhves nf tha `dmhnhStbathmn widH the prObectr col@leted !nd cclHacs(klad. Ex ep@ence h r ahjvf thad 4hen deveLopianT ppmjecda are cOim@Li i bAqa \$ owN\%rsHaP ic eNhAn ad an\$ hafbe the suqda nabiHhtx nf sDch prejebts ip eNstred H`h05,001\$ `aee 12)

\section{5 @LMM NITAEA AFE I FRGA LLDM CM MMUNI Y}

D@IB@N@RIJACPS@lpd`d9 (0 comdu.i ies `bo- the th2e\% \$oca( ggterl\%e.ts ff Ggg, Hdddcb\$ and Odagbo had ben\$fid`e $\$$ fb\&m d’e fipcd phAse nf t`e ra2ah `DfElopleft iNitiaPhves nf tha `dmhnhStbathmn widH the prObectr col@leted !nd cclHacs(klad. Ex ep@ence h r ahjvf thad 4hen deveLopianT ppmjecda are cOim@Li i bAqa \$ owN\%rsHaP ic eNhAn`ad an\$ hafbe the suqda nabiHhtx nf sDch prejebts ip eNstred H`h 05, $001 \$$ 'aee 12) 
@lpd`d9 (0 comdu.i ies `bo- the th2e\% \$oca( ggterl\%e.ts ff Ggg, Hdddcb\$ and Odagbo had ben\$fid`e\$ fb\&m d`e fipcd phAse nf t`e ra2ah `DfElopleft iNitiaPhves nf tha 'dmhnhStbathmn widH the prObectr col@leted !nd cclHacs(klad. Ex ep@ence h r ahjvf thad 4hen deveLopianT ppmjecda are cOim@Li i bAqa \$ owN\%rsHaP ic eNhAn`ad an\$ hafbe the suqda nabiHhtx nf sDch prejebts ip eNstred Hh 05, $001 \$$ aee 12)

Thic qt/py 7aA 'Rhd4el iJ a sTr!aghp L ar dkbm`t nd `bmvades hnfopma@ikn on gh `p Ejd" ct`te e/ver.mdlp iq dkIbg dop its pupal cgee!nadIac* The sdkby `s (ivever pakan a ctdp fubtheb bx the c2hdab Rdatidg Phe eaqel"a kf comlq.idy base` prgjeCtc Elsur`nd its sUqt`i*abIlity\& EZIALA-AM MAPA D@Y

\section{O@ GHJBY}

\section{EZIALA-AM MAPA D@Y O@ GHJBY}

...INDTST $\square$ IALISDQ B@OWDB COMMUJITI WITH DDVELOPIANT CI DA

$\mathrm{nb}$ thA peg0le Of thE cty Cdd d\%m`lt mf Azhala-AmUmara aqTnNomoup cg-m0lhtY hj Azinihi te Mbahse hncal ckrdbjMenT ab\$a Nf HMg c@ate, It u`s `ahbabj bdbendlY `b `hey appreciated those who had in one way or the other assisted to liberate the community from the shackles of underdevelopment. (March 5, 2009, page 42)

\section{GROUP DONATES N25M MATERNITY COMPLEX TO COMMUNITY}

Chief Basil Okeke said, "this maternity and health centre is the brainchild of the progressive and development consciousness of the members of the Old Brothers Association. We deemed it fit and necessary to provide sustainable healthcare delivery system for the teeming population of our people at home, particularly at home, particularly our mothers and wives." (May 2, 2011, page 10)

The purpose of these stories is to show and tell other influential citizens of other communities to give something back to the community as was done to the Eziala-Amumara autonomous community. The writer is trying to tell the public that they do not have to wait for the government to do everything, they can also take some constructive steps on their own.

\section{OYO: PORTRAIT OF A THRILLING TOWN}

A trip to the ancient city of Oyo today would make one wonder whether one is really in the ancient city that was conquered amny empires in the past centuries. Of all the Yoruba kingdoms, the Oyo Empire was the largest and most powerful. (March 11, 2009, page 46)

This story is an in-depth story written to shed light on the Oyo empire. It tells of its history and reputation, its attractions and level of hospitality. It seeks to provide information on one of the most historic towns in the Yoruba kingdom.

\section{ENUGU COMMUNITY STOPS TRADITIONAL RULERS FROM DISPOSING LANDED PROPERTY}

Rising from its general meeting, the Ahani-Achi Development Union (ADU) reminded the traditional rulers that such powers over the community's landed property was solely vested with the development union executive. (May 9, 2011, page 10)

This story shows citizens exercising their rights as individuals and as associations. It reveals the fact that traditional rulers no longer have such authoritarian power over their constituents. This in itself shows development not only in infrastructure but in the minds of people and most likely the writer of this piece had this in mind.

\section{Summary and Conclusion}

This study was carried out to ascertain the extent of selected newspapers' reportage of rural development, realizing the implications which rural developmen have for national development. The study determined the reportage of rural development issues in Nigeria within a period of two years (2009 and 2011). The study investigated the extent of social responsibility displayed by selected newspapers in reporting the issues. The newspapers selected for the study included Nigerian Tribune, The Punch, The Guardian and the Daily Sun. The study adopted a combined use of content analysis and dialectical hermeneutics style of textual analysis. The study was conducted within the period of 2009 and 2011 . It was discovered that agricultural development stories and infrastructural development stories were the most reported by the selected newspapers. Cultural stories accounted for the least coverage by the selected newspapers. It was also observed that all the selected newspapers made use of the straight news format most often than the other journalistic genres. By way of general placement of stories, the newspapers gave less prominence to rural development stories by placing the majority of the stories on inside pages. The selected newspapers placed insignificant premium on rural issues as evident in the inadequate placement of stories on front pages and paucity of in-depth and interpretative analysis of issues. Also, the selected newspapers devoted a considerable percentage of their overall rural 
development oriented stories to agricultural development and infrastructural development. The Nigerian press as an institution or organ is expected to report all or every sector of the Nigerian economy with sufficient attention on each sector. This becomes necessary because each sector of the economy is of equal importance to the development of the Nigerian society. As observed in the study, it would be necessary for the Nigerian press to give equal attention to all sectors of rural development. Congruent to the findings of this study, the following recommendations are made:

1. Community newspapers should be established for the primary aim of canvassing and monitoring development policies and projects including focusing attention on the development needs of the rural people.

2. Every newspaper house should create development desk just as there exist foreign, sports, business desks, among others. With this, there will be increased coverage of development activities.

3. Correspondents should be employed from amongst the rural people. They should be trained and made to cover their areas.

4. Furthermore, the press should adequately utilize its developmental function for the positive change and development of the rural sector.

\section{References}

[1]. Barton, F. (1979). The Press of Africa. London and Basingstoke, The Macmillian Press Ltd.

[2]. Bello, R. \& Ajayi, O.O.S. (2000). Research Methods \& Statistical Analyses. Ilorin, Haytee Press and Publishing Limited.

[3]. Bullock, R. H. (2006). The Norton Field Guide to Writing. New York, W. W. Norton and Company.

[4]. Diso, L.I (2005). Information, production, transfer, and delivery: Mass information work and television journalism dilemma in Nigeria. The International Information and Library Review

[5]. Edeani, D. O. (1993). Role of Development Journalism in Nigeria's Development. Gazette 52

[6]. Harande, I. Y., (2009). Information Services for Rural Community Development in Nigeria. Library Philosophy and Practice, Kano.

[7]. Ifenkwe, G. E. (2008). Assessment of Newspaper Advocacy for Rural Development and Environmental Education in Nigeria. Journal of Agricultural Extension, Vol. 12 (2).

[8]. Inayatullah, I. (1967). "Towards a non-Western Model of Development” in Schramm, W. and Lerner, D. (eds.) Communication and Change in Developing Countries. Honolulu: East-West Center.

[9]. Jimoh, I. (1992). Nigerian Press and Rural Development: A comparative study of Weekly Trust and Gaskiya Tafi Kwabo's Coverage of Health Activities

[10]. Jimoh, I. and Modiobo, M. (2005). "Markandaya's 'Technology, Environment and Employment in Third World.” Being an Article review, presented at Department of Mass Communication B. U. K., Kano.

[11]. Joni, C. J. (1997). Mass Media and Rural Development. Rawat Publications,Lagos.

[12]. Locksley, G. (2009). The Media and Development: What's the story? World Bank Working Paper No. 158. Washington D.C.

[13]. Malam, N. M. (2005). "The Scope and Application of 'Development news' by Nigerian Newspaper Journalists" in Africa. Broadcast Journal vol. 1, No 1.

[14]. McKee, A. (2003). Textual Analysis: A Beginner's Guide. United States of America, Sage Publications, California.

[15]. Okiy, R.B. (2003). Information for rural development: Challenge for Nigerian rural public ibraries. Library Review 52 (3).

[16]. Okorie, N., Oyedepo T. (2011). Newspaper Reportage and its Effect Toward Promoting Agricultural Development in Nigeria. Journal of Media and Communication Studies, Vol. 3 (2),

[17]. Rivers, L. W., \& Schramm, W. (1969). Responsibility in Mass Communication. Harper \&Row Publishers, New York, Evanston and London.

[18]. Schramm, W. (1964). Mass Media and National Development: The Role of Information in the Developing Countries. Stanford, Stanford University Press.

[19]. Seers, D. (1997). The Meaning of Development in Uploff, T.N. and Warren, E.K. (eds.). The Political Economy of Development: Theoretical and Emperical Contributions. Berkeley, Los Angeles: University of California Press.

[20]. Soola, E. O. (2005). Communication for Development Purposes. Ibadan, Kraft Books Limited.

[21]. Tejumaiye, A. (2003). A Mass Communication Research: An Introduction. Nigeria, Ibadan Sceptre University Press.

[22]. The Nigerian Journal of Communications: The Bi-Annual Journal of the African Council for Communication Education (ACCE), Nigeria Chapter Vol. 6, Number 1 \& 2, 2008 Editor in chief: Prof Ikechikwu E. Nwosu, Rhyce Kerex Publishers, 25, Ogunbiyi Lano, Ogui, Enugu, Nigeria.

[23]. Trochim, W. M. (2006). The Research Methods Knowledge Base. Retrieved from http://www.socialresearchmethods.net/kb/

[24]. Udoakah, O. (1998). Development Communication. Stirling-Horden Publishers, Ibadan, Lagos.

[25]. Uwakwe, O. (2007). Communication and National Development. Cecta Nigeria Limited, Enugu.

[26]. Wilson, D. (1997). Communication and Social Action. Foodstep Publications, Port Harcourt. 